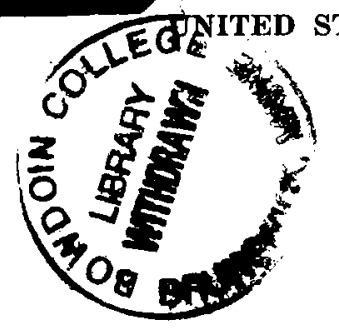

Harold L. Ickes, Secretary

GEOLOGICAL SURVEY

W. C. Mendenhall, Director

Bulletin 849 - H

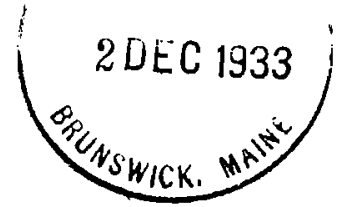

\title{
THE VALDEZ CREEK MINING DISTRICT ALASKA
}

\author{
BY \\ CLYDE P. ROSS \\ $+1$
}

Investigations in Alaska Railroad belt, 1931

(Pages 425-468)

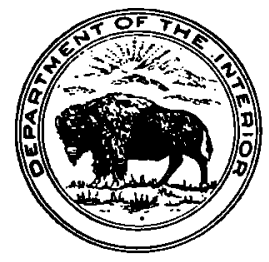

UNITED STATES

GOVERNMENT PRINTING OFFICE metadc304236

WASHINGTON : 1933 



\section{CONTENTS}

Foreword, by Philip S. Smith.

Abstract._._._._._._._. 425

Introduction

Geography _.

History _. _.

Stratigraphy and petrology

Greenstone........... 429

Limestone........... 430

Lenses between Clearwater Creek and the Susitna River _. _. _ $\quad 430$

Beds in the valley of Coal Creek.

Limestone mass north of Coal Creek

Tuffaceous and related strata._._.

Rusty schist...._._._._._. 435

Argillite......

Schist near Valdez Creek.

Tertiary (Eocene ?) strata._.

Quaternary deposits......... 439

Intrusive rocks.

Gneissic quartz diorite...

Other dioritic rocks.

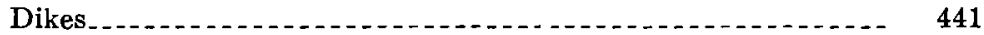

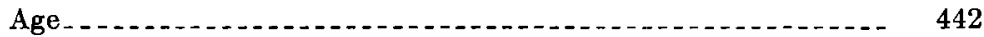

Structure. _.

Folding

Faulting

Economic geology _...

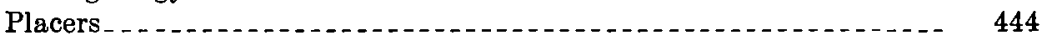

Relation of placers to geomorphology

Placer workings........ 449

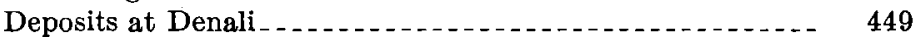

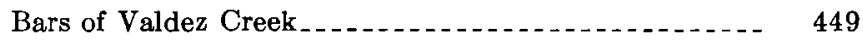

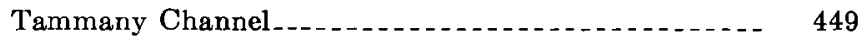

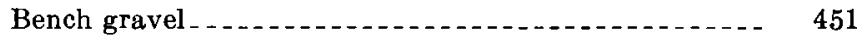

White Creek

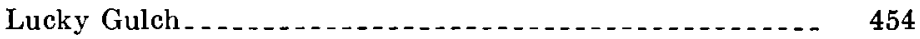

Other workings.

Lodes

Veins with quartz as the essential gangue mineral _._.

Veins containing calcite...... 457

Pyritic replacement deposits...... 458

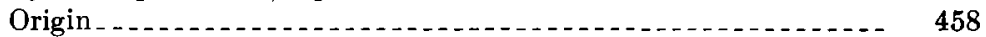

Suggestions for development

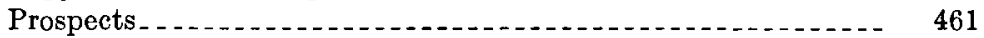

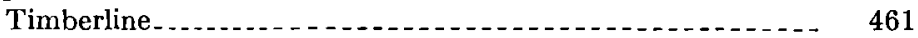

Gold Hill _. . .

Small prospects near Valdez Creek................... 463

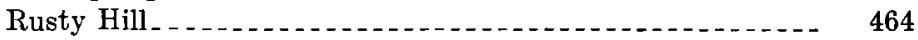

Mineralization east of Clearwater Creek _........... 464

Coal_._._._._._._. 465

Index 


\section{ILLUSTRATIONS}

Prate 34. Geologic sketch map of the Valdez Creek mining district

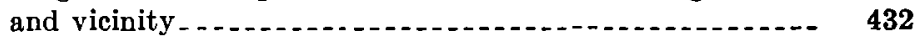

35. Placer claim map of the Vuldez Creek mining district_...... 448

Figure 1. Index map showing areas investigated in Alaska Railroad belt,

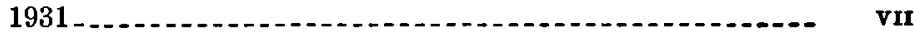

53. Probable location of buried channels near Denali with reference to present drainage

54. Contour map of the Tammany Channel.............. 450

55. Contour map of hydraulic cut on the Folk claim _........ 452

56. Sketch map of the lodes on the Timberline prospects........ 461

IV 


\section{INVESTIGATIONS IN ALASKA RAILROAD BELT, 1931}

FOREWORD

By Philip S. Smith

To help the mining industry of Alaska and to assist in the development of the mineral resources of the Territory have been the prime motives of the Geological Survey's investigations in Alaska during the past 35 years, in which nearly one half of the Territory has been covered by its reconnaissance and exploratory surveys. It was natural, therefore, that the Alaska Railroad, when it undertook intensive consideration of the problem of finding tonnage that would increase its revenues, should look to the Geological Survey to supply technical information as to the known mineral deposits along its route and to indicate what might be done to stimulate a larger production of minerals and induce further mining developments and prospecting that would utilize its service. Realization of the need for this information had long been felt by the officials responsible for the operation of the Alaska Railroad, and the need had been partly supplied by the Geological Survey, but funds to carry through an extensive inquiry of this sort had not been available until 1930, when a special committee of the Senate, composed of Senators Howell, Kendrick, and Thomas, visited Alaska, studied some of the railroad's problems, and successfully urged Congress to grant it $\$ 250,000$ for investigations of this kind.

On the invitation of the Alaska Railroad the Geological Survey prepared various plans and estimates for the investigations that appeared to be most likely to contribute the desired information as to the mineral resources. Selection of the problems to be attacked proved difficult, because the choice necessarily was hedged about with many practical restrictions. For instance, each project recommended must give promise of disclosing valuable deposits-a requirement that was impossible to satisfy fully in advance, as it involved prophecy as to the unknown and undeveloped resources. Then, too, it was desirable that the search should be directed mainly toward disclosing deposits which if found would attract private enterprises to undertake their development in the near future. Finally, som; of the deposits that might be worked profitably did not appear likely to afford much tonnage to be hauled by the railroad. Under these 
limitations it should be evident that the projects that could be recommended as worth undertaking with the funds available by no means exhausted the mineral investigations that otherwise would be well justified. In a large sense, all of Alaska may properly be regarded as indirectly contributory to the welfare of the railroad, but even in that part of Alaska contiguous to its tracks there are large stretches of country that are entirely unexplored and large areas that have had only the most cursory examination. Although areas of this sort might well repay investigation, they were excluded from the list of projects recommended because they were not known to contain mineral deposits of value, and it therefore seemed better to make the selection from other areas that had been proved to hold promise. Furthermore, several areas within the railroad zone were excluded because their value was believed to lie mostly in their prospective placers, which would not yield much outgoing tonnage; others because their lodes carried mainly base metals, for which development and the recovery of their metallic content in a readily salable condition were relatively expensive; and still others because their resources consisted mainly of granite, building stone, or some other product for which at present there is only a small local demand.

After careful consideration ten projects were selected, and the funds required for undertaking them were made available. The projects that were selected involved the examination of two areas principally valuable for their coal (Anthracite Ridge and Moose Creek), five areas likely to be principally valuable for gold (Fairbanks, Willow Creek, Girdwood, Moose Pass, and Valdez Creek), and three areas whose lodes consisted mainly of mixed sulphides (the Eureka area in the Kantishna district, Mount Eielson, formerly known as Copper Mountain, and the head of West Fork of Chulitna River). The general position of these different areas is indicated on the accompanying diagram (fig. 1). A general study of the nonmetalliferous resources of the entire region traversed by the railroad was included in the projects to be undertaken, but the results obtained were not such as to permit adequate determination of their extent at this time.

Examinations were made in the field in each of the selected areas, all the known prospects and mines being critically examined and sampled so far as time and other conditions permitted. The records thus obtained, together with all other information bearing on the problems, were then subjected to further study in the laboratory and office, in the course of which other Geological Survey specialists whose knowledge and experience could be of assistance were freely consulted. The outcome of all these lines of analysis has been the reports which make up this volume. Although each chapter is presented as embodying the latest and most authoritative information available regarding the districts and properties described up to the time field work in them 


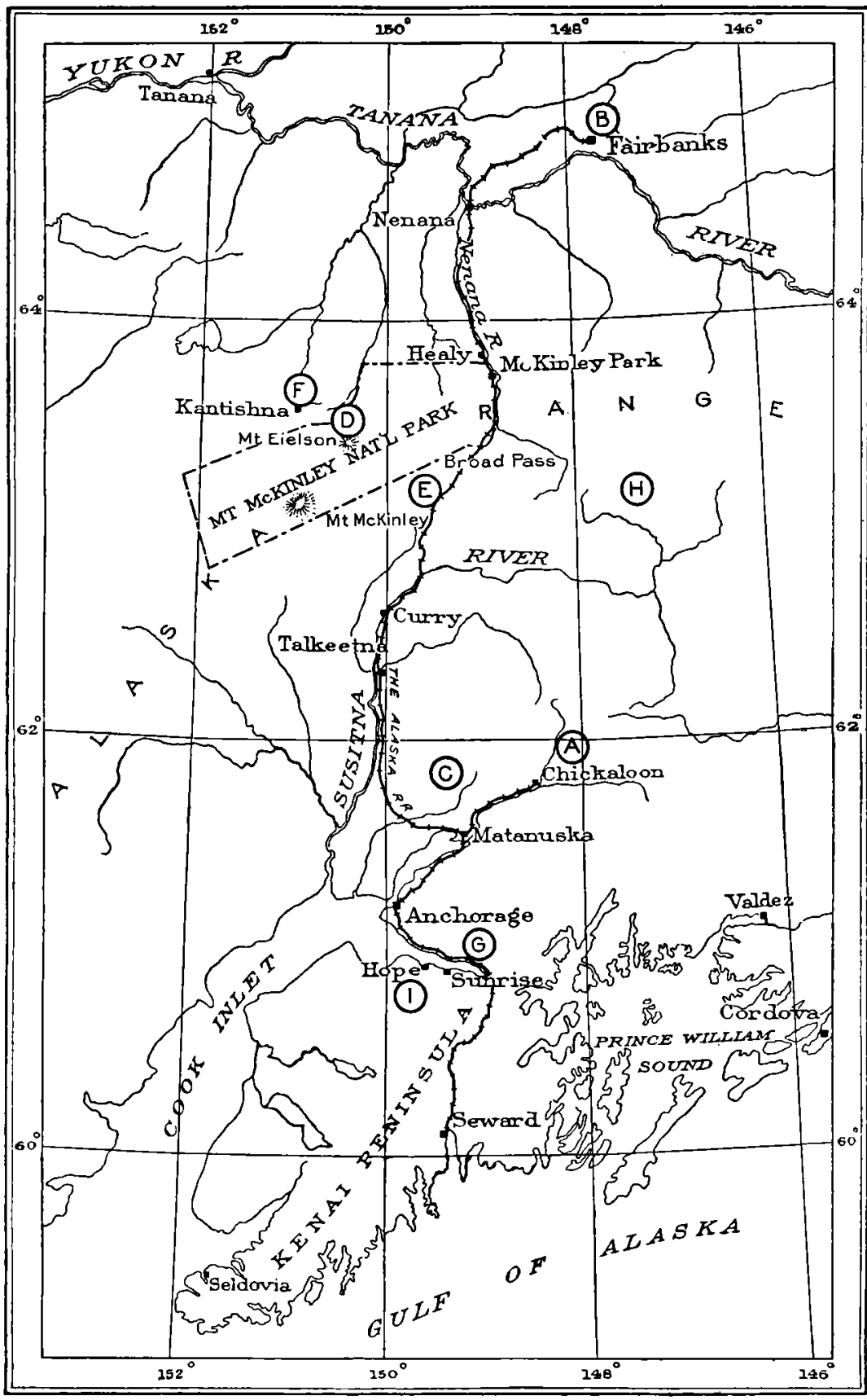

so

so Miles

FIGURE 1.-Index map showing areas investigated in Alaska Railroad belt, 1931. A, Anthracite Ridge B, Fairbanks; C, Willow Creek; D, Mount Eielson; E, West Fork of Chulitna River; F, Eureka and vicinity; G, Girdwood; H, Valdez Creek; I, Moose Pass and Hope 
was finished, the authors make no claim that all the results they have presented are to be regarded as final nor as solving all the problems that have arisen. Actually none of the mines have been developed to such an extent as to furnish all of the evidence desired to solve the problems involved. At none of the properties is any considerable quantity of ore actually "blocked out" in the engineering sense of that term, so that instead of specific measurements as to the quantity and grade of ore the different camps will yield, the Survey geologists and engineers have necessarily had to make numerous assumptions and be content with estimates and generalizations as to the potential resources. Furthermore, the work was planned so as not to invade the proper field of the private mining engineer in the valuation of individual properties, but rather to occupy the open field of considering the districts as a whole.

In two of the districts, Anthracite Ridge and Moose Creek, whose value lay in their prospective coal resources, the examinations that could be made by ordinary geologic means were not adequate to arrive at a final judgment of the resources of the area but pointed to the desirability of further tests by drilling. As a consequence additional exploration of these districts by means of diamond drilling was authorized, and this work was undertaken in the season of 1932 . The results of these tests were not available at the time the manuscripts of the other reports were completed, and rather than delay their publication until the later reports could be finished and incorporated in the volume these reports have been omitted here and will be published later elsewhere.

This is not the place to summarize the detailed findings of the geologists as to the merits of the different districts, as those findings are explained in detail and summarized in the respective chapters. Suffice it to say here that on the whole the principal purpose of the investigations was carried through satisfactorily and that while the studies in some of the districts indicate that they hold little promise of extensive mineral development in the near future, others appear to encourage development under existing conditions, and still others seem to be worth development when some of the existing factors such as transportation or price of base metals are improved. That conditions which are now temporarily retarding the development of some of the deposits will become more favorable cannot be doubted. The entire region is becoming more accessible each year, and as a result costs are being lowered and experience is being gained as to the habit of the various types of deposits, so that the conclusions expressed in this viume as to the resources of the different districts should be reviewed from time to time in the light of the then current conditions. 


\title{
THE VALDEZ CREEK MINING DISTRICT, ALASKA
}

\author{
By Clyde P. Ross
}

\begin{abstract}
The Valdez Creek mining district was one of those visited in 1931 in connection with the study of the nineral resources of the region tribuiary to the Aluska Railroad. It is underlain by argillite, schist, tuff, tuffaceous conglomerate, limestone, and greenstone, listed in approximate stratigraphic order beginning with the youngest. These rocks are probab'y all of Ulper Triassic age and form part of the north limb of a large fold that trends east to uortheast but is locally broken by faults and minor flexures. There are a number of stocklike intrusions, mainly quartz diorite and similar rock, and small basic dikes, all of Upper Jurassic or later age. One small mass of Tertiury (Eocene?) coal-bearing beds and considerable Quaternary alluvium and glacial deposits are present.

The district contains numerous auriferous quartz veins, which range in size from stringers along joints and similar openings to lodes more than 1,000 feet long and several feet wide. The larger masses lie in shear zones in which the altered country ruck is itself nineralized, and such bodies are of possible commercial vilue, although apparently not of high grade. There is sufficient evidence suggesting the existence of high-grade pockets to justify "pocket hunting", which has not get been systematically attempted in the district. Along the eastern border of the area examined during the present stuly limestone, schist, and greenstone have suffered igneous metamorphism, including the deposition of metallic minerals. This part of the area apliears to justify more prospecting than it has yet received. Sufficient coal exists here to be of some local value if a metal mine were established.

The sole productive enterprise up to the present time has been placer mining, and this constitutes the best hope for future expansion. The geomorphology indicutes that in addition to known denosits there may be large amounts of potentially valuable placer ground which cannot be economically handled under present methods of operation.
\end{abstract}

\section{INTRODUCTION}

The Valdez Creek mining district was one of the areas visited in connection with the study of the mineral resources of the region tributary to the Alaska Railroad. The party, consisting of Clyde P. Ross, geologist, and Marion Peel, packer and rodman, left Cantwell, the nearest point, on June 11, 1931, and returned there July 17. In this period geologic and topographic sketch maps of about 80 square miles of country were made ( $\mathrm{pl.34}$ ), and the placers and lode prospects were examined. The work was extended eastward beyond the 
limits of the Valdez Creek district proper to include part of the drainage basin of Clearwater Creek. The location of the area mapped is shown in figure 1.

The work was greatly facilitated by the remarkably complete and accurate geologic data embodied in Moffit's reconnaissance report on this region. ${ }^{1}$ All correlations of geologic age given in the present report agree essentially with Moffit's assignments. The base for the topographic map (pl. 34) was obtained by photographic enlargement of the plane-table sheet for this area made by D. C. Witherspoon and C. E. Giffin for the map that accompanies Moffit's report. The location of the principal peaks proved sufficiently accurate for use in triangulation, though for the larger scale here used the topographic sketching was completely revised. It was impracticable for the writer, working single-handed and with limited time, to maintain control of standard accuracy, but the map shows form with essential correctness. The datum for elevation above sea level was assumed from Witherspoon and Giffin's map and hence, as noted on that map, is about 200 feet higher than the datum in use along the Alaska Railroad. The geologic boundaries on plate 34 were sketched concomitantly with the topographic work.

\section{GEOGRAPHY}

The Valdez Creek mining district corresponds essentially to the drainage basin of the creek, which enters the Susitna River from the east about 25 miles south of the lower terminus of the Susitna Glacier in the Alaska Range. The principal development has been placer mining close to the mouth of Valdez Creek, where the post office of Denali (formerly McKinley) has been established. This point is now commonly reached by a trail from Cantwell, on the Alaska Railroad; the distance is somewhat more than 50 miles, and the trip as made with pack horses in summer generally occupies three days. Before the railroad was completed the district was reached from Valdez, Chitina, and other towns by way of the military road, now the Richardson Highway, and thence by one of several routes westward across the mountains or up the rivers.

Valdez Creek is in the southern foothills of the Alaska Range. Its mouth is somewhat more than 2,500 feet above sea level, and the highest summits in its vicinity are a little more than 6,000 feet. The hills are moderately steep, but only the highest summits are rugged. The main stream is intrenched to a maximum depth of about 150 feet for a distance of about 4 miles from its mouth. Between the upper end of the inner gorge and the mouth of Roose-

1 Moffit, F. H., Headwater regions of the Gulkana and Susitna Rivers, Alaska, with accounts of the Valdez Creek and Chistochina placer districts: U.S. Geol. Survey Bull. 498, 1912. 
velt Creek, the principal tributary, it wanders over the floor of a $U$-shaped trough, as yet scarcely dissected. All but the smallest of the tributary gulches show evidence of the former presence of minor glaciers. On both sides of the incised channel of lower Valdez Creek the ground is hummocky and in part marshy, as a result of glacial dumping.

The Susitna River in this vicinity flows in shifting channels over a broad sandy flood plain. Channels more than 5 feet deep are rarely as much as 100 yards wide, but the total width of water, swamp, and quicksand in some places is 2,000 to 4,000 feet. This stream constitutes the greatest single obstacle to travel between the Alaska Railroad and Valdez Creek.

Farther east the drainage basin of Clearwater Creek, itself a tributary of the Susitna River, is reached through a low pass at the head of Roosevelt Creek. The topography here differs materially from that close to Valdez Creek. The mountains are steeper and more rugged, and the major streams meander in flood plains incised into broad gravel-floored benches. The ground is better drained, and travel is consequently easier than it is to the west.

Groves of rather small gnarled spruce trees grow on both sides of lower Valdez Creek and other tributaries of the Susitna River up to altitudes of 2,600 to 3,000 feet above sea level. Much of the lumber for buildings and for mining operations along Valdez Creek has been obtained from Butte Creek, about a mile south of Denali and on the opposite side of the Susitna. Most of the supply of suitable trees in more convenient locations was early exhausted. The lack of timber along upper Valdez Creek has been a serious obstacle to mining operations there. Except for willows, there is no timber in the part of the drainage basin of Clearwater Creek visited during the present investigation. Moffit's map of the distribution of spruce in the Broad Pass region ${ }^{2}$ includes all of the timbered tracts in the district here considered.

\section{HISTORY}

Gold was discovered on Valdez Creek on August 15, 1903, by a party including Peter Monahan, J. S. Smith, J. M. Johnson, and J. C. Clarkson. ${ }^{3}$ Work started in earnest the following year, when these men returned in company with a number of others. Most of the claims shown in plate 35 were staked at this time, but nearly all the production in the early years came from the immediate vicinity of the present site of Denali. At the height of the boom probably about 150 miners were at work.

2 Mofft, F. H., The Broad Pass reglon, Alaska : U.S. Geol. Survey Bull. 608, fig. 2, 1915.

Moffit, F. H., Headwater regions of the Gulkana and Susitna Rivers, Alaska, with accounts of the Valdez Creek and Chistochina placer districts: Bull. 498, pp. 53, 54, 1912. 
In 1912 most of the placer ground in the district was acquired by outside interests, although outlying claims continued to be worked by individuals. In 1913 to 1924 large quantities of mining supplies were brought in and hydraulic operations were undertaken by an organization known at first as the Valdez Creek Placer Mines and later as the McKinley Gold Placers and the McKinley Placer Mining Co. This company employed a maximum of about 50 men, but generally less. Most of its work was concentrated on a buried channel on the Tammany claim (see pp. 449-451), formerly worked by underground methods. ${ }^{4}$ Although considerable gold was produced during the period of the company's operations, it appears that the returns were not sufficient to counterbalance the heavy expenses incident to equipment and operation, and the company ceased work in 1924. Work in this district has always been hampered by the fact that hydraulic mining is obviously restricted to the open season, which rarely much exceeds 100 days.

For several years after company operation ceased little was done in the district except for the resumption of tunnel mining on a small scale in the Tammany channel. In 1928 hydraulic mining started on some rich gravel that had been found on the Folk claim, on the south side of Valdez Creek a short distance below the Tammany channel. Since then the principal production has come from this deposit, and the chief interest has centered in it. The total production to the end of 1930 is about $\$ 560,000$.

In the summer of 1931 there were 15 placer miners and a small native settlement at Denali, 2 men were working in the Tammany tunnel, 2 placer miners were on White Creek, and 3 more on Lucky Gulch, and the placer deposits on Rusty Creek were receiving a little attention. Gold lodes are known on the ridge between Timberline and Valdez Creeks, near Denali, and also close to Lucky Gulch, but little has ever been done on them.

\section{STRATIGRAPHY AND PETROLOGY}

The rocks of the region include metamorphosed lava and pyroclastic rocks, argillite, and schist, with subordinate amounts of limestone, sandstone, and conglomerate, locally intensely metamorphosed, and several intrusive rocks, mainly quartz diorite and similar rock, in part gneissic. Probably all the above-mentioned stratified rocks are Upper Triassic, and the intrusive rocks are Upper Jurassic or younger. Included also are a small mass of Tertiary (Eocene?) coal-bearing sedimentary ro:k and widespread, thick Quaternary clastic deposits, mainly the product of Pleistocene glaciation.

4 Moffit, F. H., op. cit. (Bull. 498), pp. 60-62. 


\section{GREENSTONE}

The somewhat metamorphosed volcanic rocks, which comprise basalt and andesite flows, breccias, and tuffs, with minor quantities of sedimentary material, may be conveniently included under the term "greenstone", although they are on the whole somewhat less thoroughly altered than this name implies. They were examined during the present study only in the valley of Coal Creek, a tributary of Clearwater Creek, but are known ${ }^{5}$ to crop out in a band roughly 15 miles wide, extending from a point east of the $\mathrm{Ri}$ hardson Highway near longitude $145^{\circ} 20^{\prime}$ southwestward to the Susitna River near longitude $148^{\circ}$, a distance of fully 85 miles.

According to the descriptions given by Moffit and Chapin and the observations made during the present study, the greenstone is composed largely of black and dark-green basalt, in part amygdaloidal. Some of the basalt consists essentially of serpentinized olivine, augite, and calcic plagioclase, with considerable chlorite and other alteration products. Other flows consist of augite and labradorite, with epidote, chlorite, sericite, and ilmenite. Some purple, green, ancl red flows which were not studied petrographically are probably of andesitic composition. Several of the separate members consist largely of subangular fragments, mainly of lava, of a maximum diameter of about an inch. Some of these members have a clastic matrix, but others appear to be flow breccias, the matrix being composed of lava similar to the fragments. Moffit's descriptions indicate that slate, fine-grained tuff. and tuffaceous conglomerate are in places associated with the flows. Isimestone lenses, locally fossiliferous, are interbedded with and overlie the flows.

The thickness of the volcanic rocks in the Valdez Creek region has nowhere been measurerl, but in and near the ralley of Coal Creek it probably aggregates 1.500 feet. Moffit ${ }^{\circ}$ calculates that the flows in the mountains south of IButte Creek. west of the Susitna River, have a thickness of 3.500 feet. and Chapin ${ }^{7}$ notes that the maximum thickness in the mountains between Butte and Watana Creeks is evidently even greater.

Moffit ${ }^{8}$ originally regarded the la va composing the greenstone in and bordering the Valdez Creek region as erupted either in late Carboniferous time or during early or Middle Triassic time, but in a later

B Mofit, F. H., Headwater regions of the Gulkana and Susitnn Ilivers, Alaskn, with accounts of the Valdez Crork and ('histnchina placer districts: U.S. Genl. Survey Bull. 498, pp. 20-30. pl. 2 : The Broad Pass region. Alaska: IT.S. Geol. Survey Bull. 608, pp. 35-38, pl. 2. 1915. Chapin, Theodore, The Nelchina-Susitua reglon: U.S. Geol. Survey Bull. 668, pp. $26-27$, pl. 2. 1918 .

- MIoffit, F. H., op. rit. (Bull. 608), p. 27.

1 Chilpin. Theodore, op. cit. ([iull, 668), p. 27.

8 Moffit, F. H., op. cit. (Bull. 498), pp. 29-30. 
paper ${ }^{9}$ he assigned it to the Mesozoic rather than to the Carboniferous. Both Moffit and Martin ${ }^{10}$ call attention to the resemblance in character and stratigraphic position between the strata here describerl and the Nikolai greenstone of the Chitina Valley and suggest approximate correlation with that formation. Observation during the present investigation shows that the greenstone of Coal Creek is interbedded with limestone, which locally contains Upper Triassic fossils, and Moffit has shown that similar fossiliferous limestone overlies the greenstone to the southwest. (See below.) This evidence that part of the thick greenstone group is of Upper Triassic age strengthens Moffit's conclusion that none of it is as old as Carboniferous.

\section{LIMESTONE}

For convenience of description the limestones mapped in the Valdez Creek region may be divided into (1) the lenses near the upper contact of the greenstone in the area between Clearwater Creek and the Susitna River, (2) the beds in the valley of Coal Creek, a tributary of Clearwater Creek from the east, and (3) the large mass of rusty limestone north of Coal Creek. There are numerous minor lenses of limestone in the argillite, not distinguished on plate 34 .

\section{LENSES BETWEEN CLEARWATER CREEK AND THE SUSITNA RIVER}

In the mountains south of Pass Creek several lenses of limestone are exposed. Moffit ${ }^{11}$ has mapped 10 such lenses in the area between Clearwater Creek and the Susitna River. On the basis of his work several of these beyond the limits of the present study are included on plate 34 , their contacts being drawn in dashed lines. Moffit collected Triassic fossils from a limestone lens overlying basalt a short distance south of the mouth of Pass Creek. Another of the limestone lenses is on the west side of the principal tributary that enters Pass Creek from the south, in the lower part of the tuffaceous unit. This limestone is crystalline and resembles some of the less altered parts of the large mass north of Coal Creek. On the margins of the lens it is interbedded with a small amount of rusty siliceous schist identical in appearance with that north of Coal Creek. No traces of fossils were observed. The absence of fossils and the crystalline character of the rock link it with the limestone farther southwest. Moffit suggests that either this crystalline limestone may differ in age from the fossiliferous beds elsewhere or that its greater local alteration and lack of recognizable organic remains may be due

- Moffit, F. H., op. cit. (Bull. 608), pp. 26-28.

${ }^{10}$ Martin, G. C., The Mesozoic stratigraphy of Alaska: U.S. Geol. Survey Bull. 776, pp. 38-39, 1926.

11 Moffit, F. H., op. cit. (Bull. 498), pp. 31-33, pl. 2. 
to local igneous metamorphism caused by the presence of intrusive rocks close at hand. So far as present evidence goes, Moffit's second explanation appears the more probable. About 300 feet vertically above the limestone lens on the west side of Pass Creek there is an exposure of dioritic rock so intensely altered hydrothermally as to be scarcely recognizable.

\section{BEDS IN THE VALLEY OF COAL CREEK}

On the south flank of the valley of Coal Creek there are exposures of fossiliferous limestone in fault contact with greenstone. Beds 2 to 6 inches thick of massive somewhat impure limestone are interleaved with platy calcareous strata. The rock is nearly black on fresh surfaces but weathers to a light rusty brown. Fossils are rather abundantly preserved on shaly partings. Disturbance, probably due to faulting, prevents accurate measurement, but these beds and similar limestone in the north bank, which is in part more sandy, probably have an aggregate thickness of fully 500 feet. Material from blocks in the creek bed collected by Moffit and regarded by him as derived from beds on the north slope, was assigned definitely to the Upper Triassic by Stanton because it contains Pseudomonotis subcircularis. The collection (U.S.Nat.Mus. No. 15953) made during the present study from the beds on the south slope contains this same fossil, according to J. B. Reeside, Jr. On the north side of the valley limestone corresponding in appearance to the fossiliferous beds was noted only close to creek level, mantled by talus, but farther up the slope rusty and locally brecciated and slickensided limestone projects in places through talus composed mainly of volcanic rocks. Unbroken masses of the volcanic rocks crop out here and there. In one exposure brecciated limestone lies against andesite, but neither has recognizable bedding. The general relations on this slope indicate with little probability of error that the limestone and greenstone are interbedded.

\section{LIMESTONE MASS NORTH OF COAL CREEK}

Immediately north of the valley of Coal Creek a large mass of limestone is exposed. Most of it is rather fine grained, crystalline, and light gray to pinkish buff, and in nearly all exposures it is surficially very rusty. It generally has well-defined thin banding, emphasized here and there by films of sandy material, and locally grades into calcareous shale so jointed as to break in long slivers. Both the limestone and the shaly beds in many exposures are intricately crenulated. Much of the limestone contains abundant chlorite and epidote. Some of the outcrops within the limestone mass are composed of rusty siliceous schist and others of chloritized rock, 
both apparently lenses intercalated in the limestone. One of the chloritic rocks studied microscopically is an altered basalt, probably of effusive origin. It contains plagioclase, augite, calcite, epidote, chlorite, secondary quartz, and leucoxene. A few of the more sericitized plagioclase grains have such high indices of refraction as to indicate a composition approximating that of labradorite, but most of them appear to be albite-oligoclase. The plagioclase is in ragged laths, most of which are 0.3 millimeter or less in length with a tendency to flow structure. Some of the plagioclase is in phenocrysts about 1 millimeter long, and the augite also tends to form phenocrysts. 'The limestone mass as a whole is inclined northward at high angles. In many exposures the beds stand nearly vertical. Contortion and faulting make measurement of the thickness of the limestone impracticable, but it doubtless exceeds 1,000 feet. There is evidence of faulting along its southern margin, but the displacement probably is not great, and the mass belongs stratigraphically above the greenstone on Coal Creek. It appears that the two groups of beds grade into each other as is suggested by the presence of rusty limestone within the greenstone and of lenses of igneous rock within the limestone mass. 'The limestone is interbedded with, and is evidently stratigraphically below the siliceous schist north of it. 'Though the evidence is inconclusive, it strongly suggests that this large mass of rusty limestone is of Upper Triassic age and corresponds in approximate stratigraphic relations to the smaller, locally fossiliferous limestone lenses mapped by Moffit farther southwest. These limestone lenses are not every where at the same horizon.

\section{TUFFACEOUS AND RELATED STRATA}

The mountains south of the pass at the heads of Roosevelt and Pass Creeks are composed of tuffaceous conglomerate and somewhat altered tuff, with some basalt, slate, sandstone, and limestone. Observations along the east side of the South Fork of Pass Creek and Moffit's field notes for the area still farther east indicate that the strata in the mountains on the south side of lower Pass Creek are composed of slate, sandstone, and volcanic rocks, with some limestone lenses; hence the rocks in that area are tentatively correlated with the tuffaceous unit here described.

In most exposures of this unit visited during the present study conglomerate is abundant, and in the mountain faces immediately southeast of the pass leading to Roosevelt Lake it probably makes up more than three fourths of the beds. Here the major part of the conglomerate is composed of well-rounded elliptical pebbles half an inch to 6 inches in maximum diameter, with a few larger cobbles. 

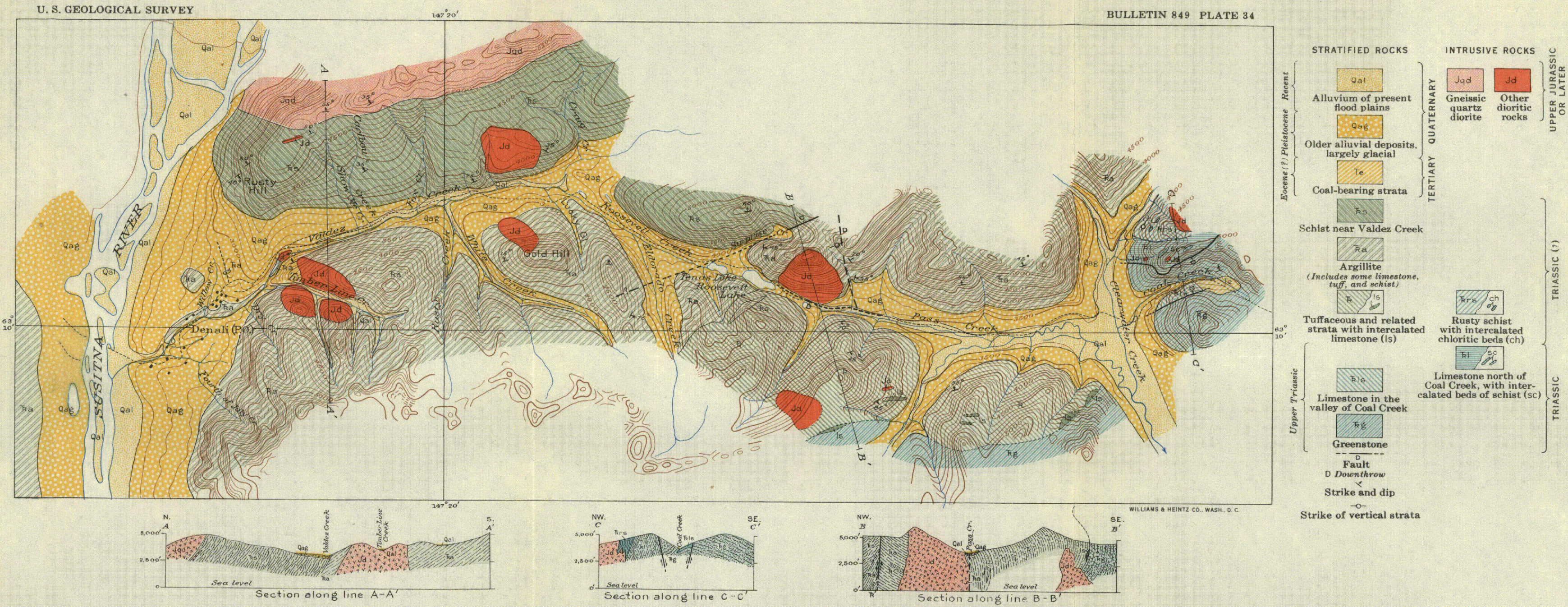

Strike of vertical strata

GEOLOGIC SKETCH MAP AND SECTIONS OF THE VALDEZ GREEK MINING DISTRICT AND VIGINITY, ALASKA

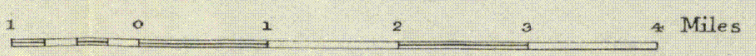



The pebbles are neither well sorted nor distinctly stratified. Most of them are black, red, purple, and green greenstone, but some are shale and sandstone. The matrix is a coarse green grit composed mainly of fragments of greenstone, quartz, and feldspar and colored by chlorite. Along the South Fork of Pass Creek the conglomerate is somewhat less abundant and the pebbles composing it are on the average smaller and more irregular in shape. The conglomerate farther east, south of Roosevelt Lake, is composed mainly of wellrounded pebbles less than an inch in maximum diameter, comparatively well sorted. Many of the pebbles are of fine-grained black rock. Conglomerate is widely distributed in this part of the area but probably makes up less than half of this unit. All the conglomerate observed, although composed mainly of igneous material, shows evidence of transportation of its constituents by water. The conglomerate is interstratified with coarse green and black chloritized feldspathic grit. These beds are too much altered for positive identification without extensive microscopic study but are doubtless mainly water-sorted tuff which has been somewhat altered hydrothermally.

Basaltic lava flows are rare and inconspicuous components of the tuffaceous unit. A specimen from one such flow exposed south of upper Pass Creek was found under the microscope to consist mainly of calcic plagioclase laths, with less than 10 percent of augite and hornblende and scattered grains of titaniferous magnetite. There is considerable sericite and chlorite and some epidote. The plagioclase laths and to a somewhat less extent the augite prisms have a rough parallelism indicating flowage. They vary in length from 0.2 millimeter to well over 1 millimeter and are embedded in a finegrained matrix that was perhaps originally in part glassy. This characteristic lava texture coupled with the fact that the rock is interstratified with obviously clastic beds shows that the basaltic rock is of effusive rather than intrusive origin.

The thickness of the tuffaceous and conglomeratic strata here cannot be determined until the structure of the unit is better understood. Doubtless the structural disturbances indicated by marked variations in the attitude of the strata in different localities account in part for the great width of outcrop in these generally steeply dipping beds, but with due allowance for this factor the indications are that the unit has a thickness of several thousand feet. (See pl. 34.)

Much of the conglomerate and grit, especially south of upper Pass Creek, appears to be partly silicified. Rather large lenses of limestone both east and west of the South Fork of Pass Creek have already been mentioned (pp. 430-431), and there are some smaller ones. $179229-33-3$ 
Limestone is, however, nowhere an abundant constituent of the tuffaceous unit.

Argillaceous beds are sparsely distributed through the gritty strata west of the South Fork of Pass Creek and are somewhat more abundant east of this stream. They are plentifully interbedded with the conglomerate and tuffaceous grit bordering the most easterly of the tributaries of Roosevelt Creek from the south. Many are indistinguishable lithologically from the rock characteristic of the main argillite mass to the north and west, but most contain somewhat more chlorite and in other respects tend to resemble and grade into the feldspathic grits with which they are associated.

Final decision as to the stratigraphic relations of the unit must be postponed until additional structural and other data are available, but it seems clear that the time of deposition of these tuffaceous beds cannot differ greatly from that of the argillite, on the one hand, or the greenstone, on the other, and the unit is in consequence tentatively regarded as of Triassic age. The evidence obtained in approaching the area from the east strongly suggests that the tuffaceous beds immediately overlie the greenstone containing lenses of limestone. Some of the lenses at and near the base of the tuffaceous unit have yielded Upper Triassic fossils, indicating that the tuffaceous unit is of Upper Triassic age. The presence of basaltic flows intercalated in the tuffaceous rock links this unit with the underlying dominantly basaltic greenstone. The coarse gritty and conglomeratic beds of the tuffaceous unit are mainly water-laid but not well sorted and contain limestone lenses; they were probably laid down along a seacoast, partly in stream valleys, partly in the sea. They record rapid erosion of the greenstone beneath, accompanied by some eruptions, probably in part explosive, in the final stages of the volcanism of which the greenstone was the principal product.

On the other hand, the tuffaceous beds south of Roosevelt Lake, which belong to the same stratigraphic unit, are undoubtedly interstratified with and conformably overlie argillite beds that evidently constitute an integral part of the argillite extensively exposed to the north and west. The most probable explanation of the relations here appears to be that argillite both underlies and overlies the tuffaceous unit, which thus constitutes a local, intercalated member in the thick argillite sequence. The interposition of wide detritus-floored valleys between the tuffaceous beds and the argillite to the north obscures the evidence and has resulted in failure to obtain proof of this hypothesis. Faults are known to exist in the vicinity, and the detritus may conceal faults of considerable displacement. The most probable explanation of the structure (outlined on pp. 442-444) accords with the interpretation of the stratigraphy here offered. 


\section{RUSTY SCHIST}

There are two distinct kinds of schist in the area studied. One of these is a rusty, siliceous variety, of which the principal body lies east of Clearwater Creek and north of Coal Creek and extends far beyond the limits of the area mapped. It has a light heliotrope color, but much of it is stained yellow by iron oxide. The rock is much crinkled, fairly hard, and locally calcareous. A few lenses of chloritic rock resembling the volcanic rocks in the adjoining limestone are interbedded with it. The portion of the schist mass within the area mapped probably has a thickness of nearly 1,000 feet.

This schist stands nearly vertical, but its contact with the large limestone mass just south of it appears to be inclined steeply north. As these two rocks are interbedded in the vicinity of the contact, it is probable that the schist overlies the limestone conformably. The limestone is of probable Upper Triassic age (see p. 432), and the schist may be tentatively regarded as of nearly the same age, although there is nothing to preclude its being as young as Jurassic. Under the interpretation of the structural and stratigraphic relations of the formations in this vicinity here given, the schist appears to be stratigraphically well over 1,000 feet above the Upper Triassic limestone on Coal Creek.

The presence of lithologically indistinguishable limestone and schist low in the sequence of tuffaceous beds on Pass Creek indicates that the contrast in metamorphism between the limestone and schist east of Clearwater Creek and the sedimentary rocks west of it are due to local modification of the rocks, probably through igneous agencies, rather than to difference in age.

\section{ARGILLITE}

The most abundant rock in the area is argillite. It is the principal rock on the south side of Valdez Creek and on the north side of Pass Creek throughout the length of these streams. Similar beds have been traced by Moffit ${ }^{12}$ and Chapin ${ }^{13}$ as far west as longitude $148^{\circ} 25^{\prime}$ near the Talkeetna River, and these may correspond approximately to the argillite of probable Triassic age which covers large areas still farther west and south. ${ }^{14}$

Within the Valdez Creek region the beds here included under the term argillite are for the most part black to dark-blue argillaceous rocks, largely slaty, with minor amounts of impure sandstone, lime-

12 Moflit, F. H., op. cit. (BuIl. 608), pp. 29-31.

${ }^{23}$ Chapin, Theodore, The Nelchina-Susitna region, Alaska : U.S. Geol. Survey Bull. 668, pp. 27-29, pl. 2, 1918.

${ }^{14}$ Martin, G. C., The Mesozoic stratigraphy of Alaska: U.S. Geol. Survey Bull. 776, pp. $42-57,1926$. 
stone, and tuff, totaling thousands of feet in thickness. In much of the argillite the cleavage parallels the bedding or cuts it at an acute angle. Locally, however, the slaty cleavage is entirely independent of the bedding. In addition to the cleavage, there is jointing, generally pronounced and locally closely spaced and forming a large angle with the cleavage. Most of the quartz veins in the argillite lie along either the slaty cleavage or the major joints. The few veins independent of these systems are generally small, and some of them are intricately crenulated.

Most of the argillite, both slaty and massive varieties, is composed mainly of quartz, sericite, chlorite, and biotite, with dark, probably carbonaceous coloring matter. Calcite is widely but in general sparsely distributed in the argillite. Locally, especially north of Pass Creek, there are small limestone lenses, and in the vicinity of some of these argillite is distinctly calcareous. In some places, mainly near intrusive bodies, the argillite, particularly the finer, more fissile varieties, glistens with sericite on cleavage faces and contains considerable chlorite. Some of the rock of this sort is essentially similar to much of the schist north of Valdez Creek.

Isolated lenses of tuff were noted on Gold Hill and north of Pass Creek close to its confluence with Clearwater Creek. Similar lenses probably exist in other places in the argillite but are nowhere abundant. Those seen consist of largely subangular fragments of several kinds of lava and broken crystals of quartz and sericitized feldspar, mainly plagioclase of intermediate composition. The matrix in which the fragments are embedded is largely fine-grained quartz of detrital origin. Biotite, chlorite, epidote, and leucoxene are also present.

No direct paleontologic evidence as to the age of the argillite in the region studied during the present investigation is available, although Moffit ${ }^{15}$ found nondiagnostic fossils in a limestone lens exposed in a gulch tributary to Pass Creek from the north, a locality which would appear to be within the argillite area as here mapped. Moffit ${ }^{16}$ grouped these beds, the tuffaceous and related strata south of Pass Creek, the rusty schist and neighboring limestone north of Coal Creek, and part of the greenstone in the valley of Coal Creek as one unit on his geologic map. As thus grouped, the limestone from which he collected Upper Triassic fossils is intercalated in the lower part of the unit, which, as a whole, was consequently referred to the Upper Triassic. As here delimited, the argillite unit would consequently be Upper Triassic or younger.

${ }^{15}$ Moffit, F. H., op. cit. (Bull. 498), p. 31.

${ }^{16}$ Idem, pp. 31-33, pl. 2. 


\section{SCHIST NEAR VALDEZ CREEK}

In addition to the rusty schist north of Coal Creek, schist that is somewhat less siliceous occupies large areas north of Valdez and Roosevelt Creeks. It is black to dark brown, generally with a distinct silvery sheen resulting from the abundance of mica. The extent of metamorphism varies markedly in different places. Locally the rock is a fissile glistening sericite schist. Most of this variety is crowded with crystals of metamorphic silicates, of which garnet is by far the most conspicuous. Elsewhere it is green with abundant chlorite and distinctly less fissile. In some outcrops the rock differs little in appearance from much of the argillite farther south and is distinctly less metamorphosed than the more intensely schistose varieties of the argillite. It is exceptional for the rock to be so schistose that original bedding cannot be discerned. Coarse, sancly, and massive beds are less common within the schist than within the argillite, but the character and appearance of such beds in the two areas are almost identical. In some places, notably in the vicinity of Rusty Hill, massive beds are intercalated in decidedly schistose rocks, and their comparatively unmetamorphosed appearance is striking. Crenulation and contortion render any attempt to measure the thickness of the schistose strata unreliable, but plate 34 shows that the thickness is great, probably several thousand feet.

The schist has not been studied petrographically, but heavy sand concentrates from placer operations near Denali, examined by Charles Milton, of the United States Geological Survey, were found to contain abundant garnet (mostly pink, rarely yellow), green and brown hornblende, magnetite, and pyrite, slightly less abundant zircon and apatite, some staurolite, sillimanite, cyanite, and biotite, and rare epidote, hypersthene, titanite, and probably monazite. Most of these minerals probably came from the schist, and they thus serve to indicate the character of the metamorphic silicates in that rock. Some of the minerals in the sand doubtless came from the dioritic intrusive rocks, and some from the more metamorphosed varieties of the argillite.

In a very general way metamorphism is greatest close to the main body of quartz diorite, but there is much local variation. Some of the most intensely metamorphosed schist occurs in small exposures surrounded by comparatively little-metamorphosed rock. The schist in the area between the outlying dioritic stock near Fox Creek and the main mass along the ridge crest is more thoroughly metamorphosed than most of that seen elsewhere, but the schist south of the outlying mass, close to Valdez Creek, is slaty and differs little from much of the argillite. Some of the argillite close to the small stock on Gold Hill, immediately to the south, is about as schistose as any 
within the area mapped. Both the tendency to greater metamorphism near igneous masses and the irregularity in degree of metamorphism suggest genetic relation between the metamorphism of this schist and the intrusion of the dioritic rocks. Though the known mineral assemblage in the schist is not incompatible with this idea it includes a number of silicates, such as staurolite and cyanite, commonly found in crystalline schists of deep-seated origin rather than in zones of igneous metamorphism. The intrusive rocks are themselves somewhat altered (pp. 440-441). The most probable conclusion from the available evidence is that intrusion took place inder considerable pressure and that the metamorphism of the schist occurred during and subsequent to the intrusion. If, as appears probable, the intrusion took place during Jurassic time or later, the associated metamorphism is too recent to give any clue to the relative age of the schist and argillite. The resemblances noted above between the argillite and schist accord with the apparent structure (pl. 34) and indicate that they are concordant components of the same sedimentary sequence, the schist being stratigraphically the higher. The greater metamorphism of the schist would then be explained by its being both nearer the main intrusive mass and, on the whole, originally more fissile than the argillite. On this assumption the schist is of Upper Triassic or possibly Jurassic age. This conclusion accords with that formed by Moffit ${ }^{17}$ in the field. $\mathrm{He}$ points out that the possibility of faulting casts doubt on the observed stratigraphic relations. Nevertheless, the lithologic resemblances between the schist and argillite appear to require close stratigraphic relations, and the origin of the metamorphism here suggested adequately accounts for the apparent anomaly of schistose rocks stratigraphically above less metamorphosed rocks.

\section{TERTIARY (EOCENEP) STRATA}

The small mass of rather poorly consolidated sandstone, shale, and conglomerate, with some coal, which underlies much of the upper valley of Coal Creek, is strikingly different from and obviously younger than the other preglacial sedimentary rocks of the region. As most of the similar deposits elsewhere in Alaska are commonly regarded as of Eocene (?) age, these beds are so designated to distinguish them from the Mesozoic strata previously described. Moffit ${ }^{18}$ and Mendenhall ${ }^{18}$ describe a number of isolated localities of similar rocks farther east, but the occurrence on Coal Creek is the only one known in or near the Valdez Creek region.

${ }^{17}$ Mofft, F. H., op. cit. (Bull. 498), pp. 32-33.

18 Idem, pp. 35-38.

${ }^{10}$ Mendenhall, W. C., Geology of the central Copper River region, Alaska : U.S. Geol. Survey Prof. Paper 41, pp. 52-54, 1905. 
The Eocene (?) beds at this locality occupy an irregular area about 5,000 feet long and 1,500 feet wide and extend up the valley slopes to a maximum of about 500 feet above their downstream margin in the channel of Coal Creek. The bedding is nearly flat, except that along the southwestern border it is contorted and broken and locally stands vertical. The strata are everywhere discordant in attitude with the older rocks on which they lie.

The pebbles in the conglomerate are poorly rounded and range from 1 to 5 inches in maximum dimension, with scattered larger cobbles. Most of the pebbles are similar in composition to the neighboring volcanic rocks. Some of the sandstone is brown, coarsegrained, firmly cemented, and feldspathic and contains a few carbonized rootlets. Other beds are chalky white and composed of thoroughly kaolinized grains with sparse less-altered feldspars. Shaly beds are in the minority; they are yellow and light brown in color, and many are so soft as to be scarcely more than indurated clay. The principal exposure of coal is in the south bank of Coal Creek, close to the downstream margin of the Eocene (?) beds, but float indicates the presence of a number of other coal seams.

The marked discordance with neighboring rocks and the comparative lack of induration fully justify the assignment of these beds to the Tertiary, but no specific evidence permitting close dating is available within the area studied. Mendenhall ${ }^{20}$ found plant remains of so-called "Arctic Miocene"-that is, Eocene-age in somewhat similar strata roughly 55 miles farther east, which he called the Gakona formation, and the fossil plants collected from most of the numerous similar occurrences in the broad region south and east of the Alaska Range are identified as Eocene. Hence the beds on Coal Creek may be tentatively so assigned.

\section{QUATERNARY DEPOSITS}

Deposits of unconsolidated gravel, sand, and silt are abundant in all the valleys of the region. They range in thickness from a few inches to well over 200 feet. Most of the material, especially in the benches into which the present streams are incised, is clearly older than the present erosion cycle. Both the topography and the character of the material show that much of it is related to glaciation. It is doubtless of Pleistocene age.

Except along the silt-laden Susitna River, which is still fed by glaciers, the modern flood plains are narrow and the recent deposits in them are shallow.

${ }^{20}$ Mendenhall, w. C., op. cit., p. 53. 


\section{INTRUSIVE ROCKS}

\section{GNEISSIC QUARTZ DIORITE}

The ridge crest north of Valdez Creek is composed of quartz diorite that forms the southern border of a large body extending far beyond the area studied. Moffit's mapping indicates that this mass has an areal extent of well over 250 square miles, although it is in part covered by Quaternary deposits. The border portion of the mass, the only part examined during the present investigation, has a distinctly gneissic texture that results mainly from the parallel arrangement of the ferromagnesian minerals but also in part from banding due to variation in the average size of grain in the rock. Locally, in the immediate vicinity of the contact, there are dark bands probably resulting from the presence of schist slivers permeated with igneous material; here the dioritic rock breaks in thin slabs. With due allowance for its coarser texture, some of this rock is almost as schistose as the schist it intrudes. The gneissic foliation in the quartz diorite approximately parallels the contact between the diorite and schist, which, in turn, is essentially parallel with the cleavage in the schist, both in strike and in dip. Locally, apophyses of the quartz diorite somewhat finer and more silicic than the main mass have been injected parallel to the foliation of the schist at intervals for a distance of nearly half a mile south of the contact. These are rarely more than a few feet wide. One of the larger ones is shown on plate 34 (somewhat exaggerated in width).

There is local variation in composition as well as texture, but much of the quartz diorite is a coarse-grained mottled gray rock, distinctly fresher than the rocks that compose the subsidiary storks farther south. Typical material has an average grain somewhat more than 2 millimeters in diameter and contains about 45 percent of oligoclase-andesine, 30 percent of quartz, 20 percent of biotite, 4 percent of hornblende (commonly somewhat altered), and nearly 1 percent of epidote. Locally the rock contains a somewhat higher proportion of hornblende. Some of the finer-grained gneissic bands contain distinctly smaller amounts of ferromagnesian minerals than the average rock and resemble aplite in appearance. Lenses of vein quartz are locally numerous near the contact with the schist.

\section{OTHER DIORITIC ROCKS}

In addition to the batholithic mass above described numerous bodies of similar but generally more altered rock occur within the area mapped, both as stocks and as minor masses having only a few square feet of surface exposure. One of the stocks is on the ritge between Timberline and Valdez Creeks, another on Gold Hill between Lucky Gulch and White Creek, another on the north side of 
Valdez Creek between Fox and Craig Creeks, and another just north of the pass at the head of Roosevelt Creek. The small mass in the extreme northeast corner of the area mapped is part of a body of considerable size that extends well beyond this area. Southwest of it there are a number of very small masses of similar rock; the larger ones are mapped on plate 34 (somewhat exaggerated in scale). The small stock south of Pass Creek (shown with dashedline boundary on pl. 34) was mapped by Moffit ${ }^{21}$ but was not reached during the present study. A number of the gulches, particularly on the north side of Pass Creek, contain chips of similar rock in the talus, suggesting the presence of other small bodies.

The rock of the stocks and minor bodies resembles that of the batholith except that it is much more hydrothermally altered and is less gneissic in texture. It is generally colored green by the abundant chlorite. Much of it has a moderately coarse granitic texture, but some, such as that near Timberline Creek, has prevailingly lathshaped feldspars as much as 2 millimeters long, with interstitial quartz, and thus has a texture resembling that of a coarse-grained dike rock. Alteration is so prevalent that exact determination of the constituents is difficult, but it is evident that the rock in the different localities ranges in composition from quartz diorite to quartz monzonite, the average being intermediate between these extremes and approximating granodiorite. The principal original constituents are plagioclase of intermediate to sodic composition (generally 50 percent or more), microcline (none up to nearly 40 percent), quartz (generally 5 to 10 percent), biotite, and hornblende (variable up to about 15 percent). The plagioclase is intensely sericitized and in many places is rimmed with secondary albite. The biotite is generally bleached and chloritized. In most of the rock the hornblende is so altered and broken up as to be difficultly recognizable and is itself in large part the product of uralitic alteration of pyroxene. Epidote is abundant, and calcite, titanite, and leucoxene are locally plentiful.

\section{DIKES}

Small black dikes are scattered sparsely throughout the area. One exposed in the present hydraulic cut at Denali is a lamprophyre that consists principally of laths of sericitized plagioclase of the approximate composition of andesine, hornblende, and thoroughly chloritized biotite with abundant grains of titaniferous magnetite and local aggregates of secondary calcite and epidote. The other similar dikes in the area were not studied microscopically but probably have about the same composition. Moffit ${ }^{22}$ records the presence of numerous hornblende porphyries in the surrounding region.

${ }^{21}$ Moffit, F. H., op. cit. (Bull. 498), pl. 2.

22 Idem, p. 34.

$179229-33-4$ 


\section{AGE}

All the intrusive rocks above described are doubtless of essentially the same age. The principal alteration in most of them is hydrothermal. Both the alteration and the local tendency to gneissic texture appear to be closely related to the intrusive activity, and the differences in composition that exist within the area examined are such as are to be expected in offshoots of a single magmatic mass. Hence within the Valdez Creek district there appears to be no evidence in support of Moffit's suggestion ${ }^{23}$ that the dioritic intrusions in the upper Susitna region as a whole may have extended over a considerable length of time. The principal difference in metamorphism within the area near Valdez Creek is between the rock of the principal batholith on the one hand and that of the outlying smaller masses on the other, and the difference in structural relations may be quite sufficient to account for this. The direct evidence available does not permit dating the diorite rocks more closely than that they are later than Triassic and were consolidated long before the Quaternary glaciation and probably before the deposition of Eocene(?) beds. The character of the metamorphism suggests that intrusion took place at considerable depth and, consequently, that prolonged erosion has been required to expose the rocks at the surface as they are today. In accordance with Moffit's conclusion they may be tentatively regarded as of Upper Jurassic or later age.

\section{STRUCTURE}

The Valdez Creek district is underlain by part of the north flank of a large fold which trends somewhat north of east. There are minor folds and local contortions. The stratified rocks are cut by a number of stocks and dikes and are offset by several faults. Dynamic and igneous metamorphism are prevalent and, with local exceptions, increase northward.

\section{FOLDING}

The fact that the area lies on the north flank of a major fold is clearly reflected in the generally uniform easterly strike and the northerly dip of the strata. especially in the western part ${ }^{-}$of the area, where faulting is at a minimum. The trend is east to N. $50^{\circ} \mathrm{E}$., and the average within the area mapped is about N. $70^{\circ} \mathrm{E}$. All the larger rock masses are alined in conformity with this trend. Moffit ${ }^{24}$ shows that throughout most of the surrounding region similar trends are maintained, and successively older rocks are exposed from Valdez Creek southward.

${ }^{23}$ Moffit, F. H., op. eit. (Bull. 498), p. 35 .

24 Idem, pl. 2. 
The departure from the general trend in the vicinity of the confluence of Valdez and Roosevelt Creeks results in part from a flexure, probably augmented by a fault along upper Valdez Creek.

A small subsidiary anticline is exposed in the gorge of Valdez Creek above the present main hydraulic workings, and there are minor folds and crenulations elsewhere, in part related to the intrusion of igneous rocks. For example, the westernmost of the tributaries that enter Pass Creek from the north exposes highly contorted strata whose deformation is related to the nearby stock. The large mass of conglomerate, tuff, and related rocks south of this locality is inclined steeply to the south but with marked variation in attitude. The probable structure here is indicated in the structure section on plate 34 .

The limestone and schist east of Clearwater Creek are contorted and in large part intricately crenulated, doubtless as a result of combined intrusion and faulting. The rocks show evidence of having been permeated and metamorphosed by heated solutions of igneous origin, and this may have aided in rendering them incompetent. They are cut by numerous small masses of gneissic diorite, of which only a few could be mapped. These are probably offshoots of a large mass whose intrusion may have been a dominant cause of the contortion of the limestone and schist.

\section{FAULTING}

The rocks in the eastern half of the area mapped are broken by normal faults with an average trend of N. $65^{\circ}$ E. and steep northwesterly dips. Though such faults have been actually traced only for short distances, both the general relations of the rocks and the topography suggest that they persist for miles, buried under the alluvium of the valleys. Moffit ${ }^{25}$ has mapped one such fault with a length of 8 miles. If, as seems probable, the fault near Coal Creek continues along Pass Creek it would be as long. The shape of the body of gneissic diorite mapped by Moffit along upper Valdez Creek. just beyond the limit of the present study, and the offset in the schist mass suggest that a similar long fault exists here. Such a fault would trend slightly more to the north than the others mentioned above.

There is some evidence suggestive of faults trending N. $70^{\circ} \mathrm{W}$. The departure from the average structural trend along the valleys of Clearwater and Eldorado Creeks is only partly explained by the known faults of northeast trend but would be adequately accounted for by conjugate faults of northwest trend underlying the gravel of these creeks. Unless the volcanic rocks near Coal Creek are strati-

${ }^{25}$ Moffit, $\dot{F}$. H., op. cit. (Bull. 498), pl. 2. 
graphically equivalent to the conglomerate and associated rocks south of Pass Creek, it would seem that such a fault must be present along Clearwater Creek. Along upper Pass Creek the relations between the tuffaceous beds on the south and the argillite on the north indicate the probable presence of a fault of about this trend buried under the alluvium, as is shown on plate 34. East of the igneous stock in this vicinity there is much crenulation and variation in attitude and the rocks are locally sheared and broken. It is inferred that there is a fault trending about $\mathrm{N}$. $10^{\circ} \mathrm{W}$. with downthrow to the east. The combined effect of these two faults would be to elevate relatively the block of argillite which is intruded by the stock. This argillite, consequently, doubtless belongs stratigraphically low in the sequence and is to be correlated approximately with the argillite that underlies the tuffaceous unit south of Roosevelt Creek.

\section{ECONOMIC GEOLOGY}

\section{PLACERS}

The Valdez Creek mining district is primarily a placer area, essentially all its production to date being from this source. The development so far accomplished has proved the presence of extensive deposits in the immediate vicinity of Denali, and there are widely distributed and locally rich auriferous gravels elsewhere. The deposits near Denali have been profitably worked on a small scale. The one attempt so far made to operate with comparatively abundant capital was confined to hydraulicking the gravel in part of a deep filled gorge, known as the Tammany Channel. Gravel along the old channel had previously been worked by underground snethods. Auriferous gravel is known to be widely distributed over the area but has been worked only in the few localities where bedrock could be reached by a few men working with primitive equipment.

\section{RELATION OF PLACERS TO GEOMORPHOLOGY}

The oldest drainage ways of which remnants persist are the buried channels near Denali. The Tammany Channel, because of the extensive placer mining in it, is the best known of these, but there are a number of others. Tammany Channel and probably others were relatively narrow, approximately $V$-shaped rock-cut gorges that appear to have been incised in a moderately mature topography without the aid of glaciation. So far as can be judged from evidence at the surface, these gorges do not continue up the present Valdez Creek Valley as much as 5 miles from its mouth. They probably record an incipient rejuvenation which was halted by the 
raising of local baselevel, probably by the filling of the neighboring part of the valley of the Susitna River either by glacial debris or by ice. In consequence the gorges were filled with alluvium. Glaciers are abundant today on and near the headwaters of the Susitna. Extension of their limits during the Pleistocene so as to fulfill the conditions here suggested would be in accord with the klıwn history of the general region.

According to operators the richest and most extensive placer ground in the vicinity of Denali is close to the old buried bedrock surface. Concentration of this material took place mainly in the streams flowing in the rock-cut channels prior to and at the start of the interference that caused the filling. Pay gravel has also been found at two or more higher horizons in the filled channels, showing that at intervals the streams maintained themselves long enough to permit concentration of the gold.

The original discovery of placer ground was made on bars in the recent channel of Valdez Creek, which derived their gold largely from reconcentration of that in the old alluvium. Above the Tammany Channel Valdez Creek flows mainly in a rock gorge, and its bars have yielded notably less gold than those below, doubtless because much less of the old material was available for reconcentration. The deposits now filling the old channels on lower Valdez Creek, as exposed in natural and artificial cuts, are characteristically well bedded. Locally boulders are numerous and heterogeneously distributed, but it is clear that the greater part of the material was laid down in water. The scarcity of cross-bedding indicates that currents were not swift, and the thorough sorting and almost perfectly regular horizontal bedding in some places suggest ponding. A good example is found in a cut on the north side of Valdez Creek just above the mouth of Timberline Creek. Isolated boulders in the sandy beds and nearby cobble deposits record less tranquil conditions. All cuts of any considerable size expose so many cobbles and boulders that it is clear that vigorous erosion, doubtless related to glaciation, was taking place in the vicinity throughout the period of accumulation, but the largest and least-rounded boulders are almost entirely confined to the immediate vicinity of the surface of the present hummocky benches; hence it appears that the last incident of glaciation here recorded was the dumping of morainal material over the surface of the water-laid strata.

In postglacial time retreat of the Susitna Glacier and removal and spreading out of its deposits have again lowered the baselevel of Valdez Creek and permitted it to trench a new, steep-sided channel, without any direct relation to preglacial channels. This new cut 
has penetrated the detritus and become incised into rock for a distance of about 4 miles and is still in process of being extended headward. The rock walls are highest at the upper end of the trench. About three quarters of a mile above the mouth of Timberline Creek the rock walls extend more than 150 feet above Valdez Creek. For some distance below the Tammany Channel rock bluffs extend generally to heights of 30 feet or more above Valdez Creek on its south side and of 5 to 15 feet on its north side.

The trend of the Tammany Channel and the reported results of drilling by the company suggest that its headward continuation lies within the confines of the valley of Valdez Creek but north of the present stream. There are extensive gravel deposits between Denali and Rusty Hill, flanked by rock on both sides. Clark Duff drilled some holes here in the summer of 1931 in search of a channel. The results obtained, though incomplete at the time of the present study, suggest that an ancient drainage way exists here, but that bedrock is so close to the surface that the existence of a channel as large as the Tammany is unlikely.

Gravel is exposed in the flank of the Valdez Creek gorge immediately opposite the Tammany Channel and may mark the southern continuation of this channel east of the present stream. The gravel in the present main hydraulic working lies nearly flat and is locally inclined about $2^{\circ} \mathrm{E}$. The small amount of original bedrock surface now accessible is inclined westward toward Valdez Creek at an angle of more than $5^{\circ}$. The gravel deposits here, therefore, bear no known relation to any channel, present or buried. The lack of accord between dip of gravel beds and inclination of underlying bedrock suggests dumping of the gravel on a rolling surface, presumably as a delta or alluvial fan.

The swampy ground at the base of the hills east of the hydraulic cut appears to be underlain by deep alluvial deposits. The hummocky, poorly drained character of the surface and the numerous erratic boulders result from glacial dumping, but exposures (in part artificial) on the south side of Timberline Creek near its mouth show clearly that gravel extends considerably below the morainal material at the surface. Similar evidence indicates that the benches on both sides of Valdez Creek for fully half a mile back from the bluffs bordering the present flood plain of the Susitna River are composed of alluvium mantled by morainal deposits.

The most probable location of the buried channels, as deduced from the available data summarized above, is that indicated in figure 53. According to this, ancestral Valdez Creek reached the flood plain of the Susitna River, a plain wider than the present 
one, at a point 1 or possibly 2 miles south of its present mouth, and the largest buried channel should be at the foot of the mountains some distance south of the hydraulic pit now in operation. Because of the difficulty of working ground on the higher benches, relatively remote from the existing gorge, little attention has yet been paid to the gravel south of the hydraulic pit in what should be, according to the above explanation, the principal buried channel. Drilling or other exploration would be required in order to fix the limits of the channel more definitely. Except that prospecting in the highlevel gravel north of Timberline Creek is reported to have shown rich ground in places, nothing is known as to the gold content of the postulated main channel. The results of operations in the Tammany Channel and the hydraulic pit and the presence of auriferous lodes on the northeast side of Timberline Creek all suggest that a channel in the position indicated should be auriferous. At all events, this ground is worthy of careful test by anyone contemplating expansion of placer activities in the district.

The gravel along Valdez Creek above the point reached by the recent inner gorge is

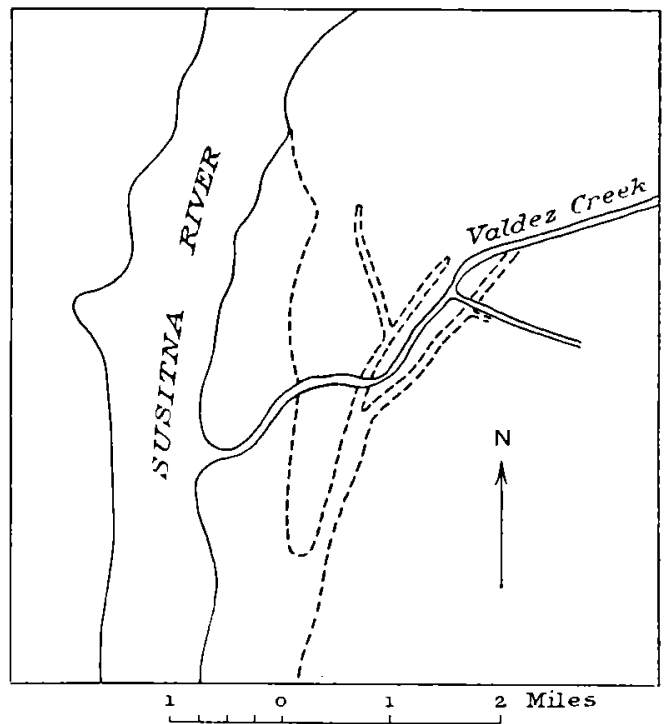

Figure 53.-Probable location of buried channels near Denali with reference to present drainage.

known to contain gold, but because of practical difficulties it has nowhere been adequately tested. Should the ancient narrow gorges uncovered near Denali not extend upstream it may well be that the concentration of the gold has been less, but on the other hand the depth of gravel would not be great-probably less than 100 feet and possibly little over 20 feet close to the present stream. The benches, especially that between White and Roosevelt Creeks, may locally have gravel deposits more than 200 feet deep. Only testing at depth can settle this point. There is ample evidence of wide distribution of auriferous quartz lodes, most of them small, in the headwater basin of Valdez Creek. The gold of Lucky Gulch and at least some of the gold of White Creek and its tributaries have 
been derived mainly from the erosion of lodes in the immediate vicinity. This fact is abundantly demonstrated by the lack of rounding and sorting in the detritus, the coarseness and angularity of the gold, and the fact that gold is not confined as closely to the vicinity of bedrock or of definite channels as is commonly the case. Several of the lodes are known and have been prospected to some extent. Placer deposits of such origin, though they may be locally very rich, are likely to be comparatively spotty and of small extent. Small-scale operations may occasionally be richly rewarded, but the hope for large production in this part of the district rests on the possibility that the relatively undissected gravel deposits of Valdez Creek from the head of the youthful trench near its mouth to its confluence with Roosevelt Creek may prove valuable.

Roosevelt Creek and the other headwater branch of Valdez Creek have comparatively steep and narrow valleys. Gravel is abundant, but the relatively steep grades and short distances from the source of the material render these valleys somewhat less favorable sites for the accumulation of placer deposits. In Roosevelt Creek, particularly, the gravel is scarcely channeled. The creek water is divided among numerous shallow and anastomosing rivulets. This lack of adjustment suggests that there has been little opportunity for the long process of sorting and concentration required for placer deposits. Such prospecting as has been done in this part of the region, mainly on Surprise Creek and other tributaries of Roosevelt Creek, was unsuccessful.

The drainage basin of Clearwater Creek differs from that of Valdez Creek in the details of its geomorphic history. The Clearwater is much the longer stream. Its gravel deposits are broader and have a flatter surface. The inner trench has been widened much more, relatively, than that of Valdez Creek and has been carried much farther upstream. This trench is distinct in all the major tributaries as far up as they were examined. All these features point to longer and more tranquil stream erosion in the Clearwater drainage basin than in that of Valdez Creek. The greater opportunity for gravitational sorting thus afforded would seem to favor the accumulation of placer deposits, provided suitably situated and abundant gold-bearing lodes were available. No placer mining has been done here, so far as can be learned. It is reported that panning of creek gravel has yielded some gold, but not enough to encourage development under existing conditions. As shown on pages $464-465$, some mineralization has occurred in the neighboring mountains, but the available information is inadequate to form any basis for estimate as to whether it could have yielded sufficient gold for commercial placer deposits. 




\section{PLACER WORKINGS}

DEPOSITS AT DENALI

BARS OF VALDEZ CREEK

The original discovery of placer gold in the district was made in the gravel bars bordering Valdez Creek, in the bend of the stream immediately above the post-office building at Denali. Claims were staked covering the present flood-plain gravel of the creek and its tributaries almost to their heads. Plate 35 is a fairly recent revision (date unknown) of the claim map of the district, but nearly all the ground indicated on it was staked in the early days. Most of the creek claims never received any development. The creek claims near Denali that have been worked to any extent are Discovery, no. 1 below, no. 2 below, no. 2 above, and no. 3 above. Of these, Discovery, no. 1 below, and the lower half of no. 2 below were the richest. ${ }^{28} \mathrm{~A}$ little more than one third of the total gold produced on Valdez Creek from 1903 to 1910 came from the creek claims, but by 1910 much of the richer ground had been worked and production from these claims declined. Except for a little hydraulic work on no. 2 below, the mining on the creek claims was done by pick and shovel. A few years later hydraulic mining in the Tammany Channel filled the creek below it with debris and brought operations there to an end.

The deposits of creek gravel on the three most productive claims ranged originally from 3 to 8 feet in thickness and consisted of fragments of slate, schist, and diorite, with small amounts of other igneous rocks. They ranged in coarseness from fine sand to boulders as much as 6 feet in diameter. The boulders, mainly diorite, were abundant and added much to the difficulty of mining. The gold from the creek claims was of variable appearance. Some was flat and well worn, but some was rough, showing little evidence of wear. That found above the Tammany Channel was finer and less worn than that below, but included a small proportion of smooth flat gold. As the decrease in coarseness is more marked downstream from the Tammany Channel than upstream, there seems to be no doubt that the richness of Valdez Creek downstream from claim no. 2 above is due to the old canyon gravel.

\section{TAMMANY CHANNEL}

On Valdez Creek immediately above the present main part of the settlement of Denali, a large excavation marks the place where the gravel fill has been removed from a section of a buried rock-cut

Mofit, F. H., op. clt. (Bull. 498), pp. 58-60. Most of the historical data and descriptions given in this report of workings now inaccessible are taken from Moffit's paper. Production figures are based mainly on the records of the United States Geological Survey. 
gorge generally referred to as the Tammany Channel, from the name of the placer claim covering it. Early in the history of the district a tunnel was driven along the bottom of this old gorge. The work was done under the leadership of Peter Monahan, and in consequence the channel is sometimes referred to by his name. This tunnel is reported to have been almost as long as the bottom of the present excavation-that is, nearly 1,000 feet. There were at least two crosscuts, and stoping was generally carried to widths of 25 to 35 feet and reached a maximum of 70 feet. The available data do not permit accurate determination of the production from the tunnel prior to company operation, but it was probably nearly $\$ 200,000$.

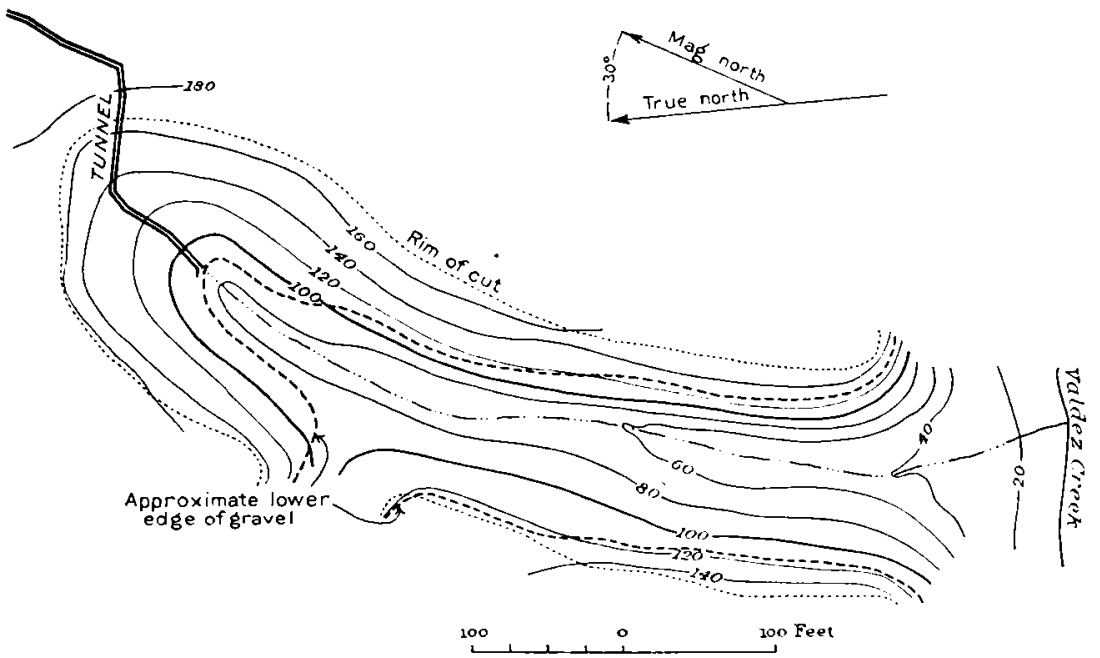

Figure 54.-Contour map of the Tammany Channel. By C. P. Ross and Fred Buck.

The gravel in the filled gorge is similar, in general, to that in the bars along Valdez Creek. The lower 500 feet of gravel in the old gorge contains flat diorite boulders with rounded edges, rounded slate and schist fragments, and fine black clay. Much of it is indis. tinctly stratified and clearly of fluvial origin. The bedrock in the bottom of the gorge, exposed by the hydraulic work, is carved and smoothed by the action of rapidly moving water, but shows no evidence of glacial polishing or scratching. The fill at higher levels presents a greater appearance of disorder and contains a large proportion of diorite boulders, which are round rather than flat. It thus resembles glacial detritus. The chief accumulation of gold is in the lower 5 feet of the gravel, although fine gold occurs throughout the fill. Most of it is found in the hard black clay and the fine gravel composed of rounded fragments of slate. Some of this finer material is sufficiently compacted to require blasting. Most of the gold is 
coarse, flattened, and smooth, though rough pieces are present. Nuggets worth several dollars are common.

The principal accomplishment under company operation in the district (see also p. 428) was the removal of about 500,000 cubic yards of fill from the Tammany Channel, as shown in figure 54, and the total production from the cut during this period is estimated at $\$ 135,000$. If the production previously obtained from the tunnel on bedrock in the same part of the channel is added, it appears that the average value of the gravel removed was roughly 65 cents a cubic yard. As much of this gravel was almost barren, the pay streaks must have been rich.

Since the cessation of company activity tunneling in the fill at the bottom of the gorge has been resumed. A winding tunnel 350 feet long had been driven at the time of survey, June 26, 1931. (See fig. 54.) Stopes, not shown because largely filled, have been opened along this tunnel, and gold has been obtained from them. The production in 1928 and 1930 amounted to $\$ 4,168$.

BENCH GRAVEL

In addition to the work in the Tammany Channel, above described, there have been several attempts to work the gravel in the high benches on both sides of Valdez Creek close to Denali. The only place where much has been accomplished is in the hydraulic cut being operated at present on the Folk claim. Rich ground here was discovered by natives about 1927 . Since then it has been worked with hydraulic equipment salvaged from that left by the company and has yielded by far the greater part of the gold recovered in recent years. About 100,000 cubic yards of gravel had been removed up to July 13, 1931. (See fig. 55.) The total production in 1928 to 1930 was about $\$ 57,000$. With due allowance for gold in the sluice boxes at the time the survey was made this indicates an average value of about 70 cents a cubic yard. This value agrees reasonably well with the estimate of 65 cents a cubic yard for the Tammany Channel and suggests that the high-level gravel deposits near Denali are quite rieh enough to warrant consideration of the feasibility of working them on a large scale. The benches on both sides of Valdez Creek here probably contain well over $2,000,000$ cubic yards of gravel, as yet practically untested.

The gravel on the Folk claim is not confined to a gorge as restricted as the Tammany Channel, although doubtless deposited at about the same time. Most of the deposit, however, is distinctly bedded, well rounded, and fairly well sorted, being quite evidently water-laid rather than of glacial origin. On top there is a soil cover several fect leep containing scattered boulders. Most of the gravel is com- 
posed of cobbles less than 1 foot in maximum diameter, but boulders as much as 4 feet in diameter are common, and a few are as much as 10 feet. The large amount of blasting needed to break up the

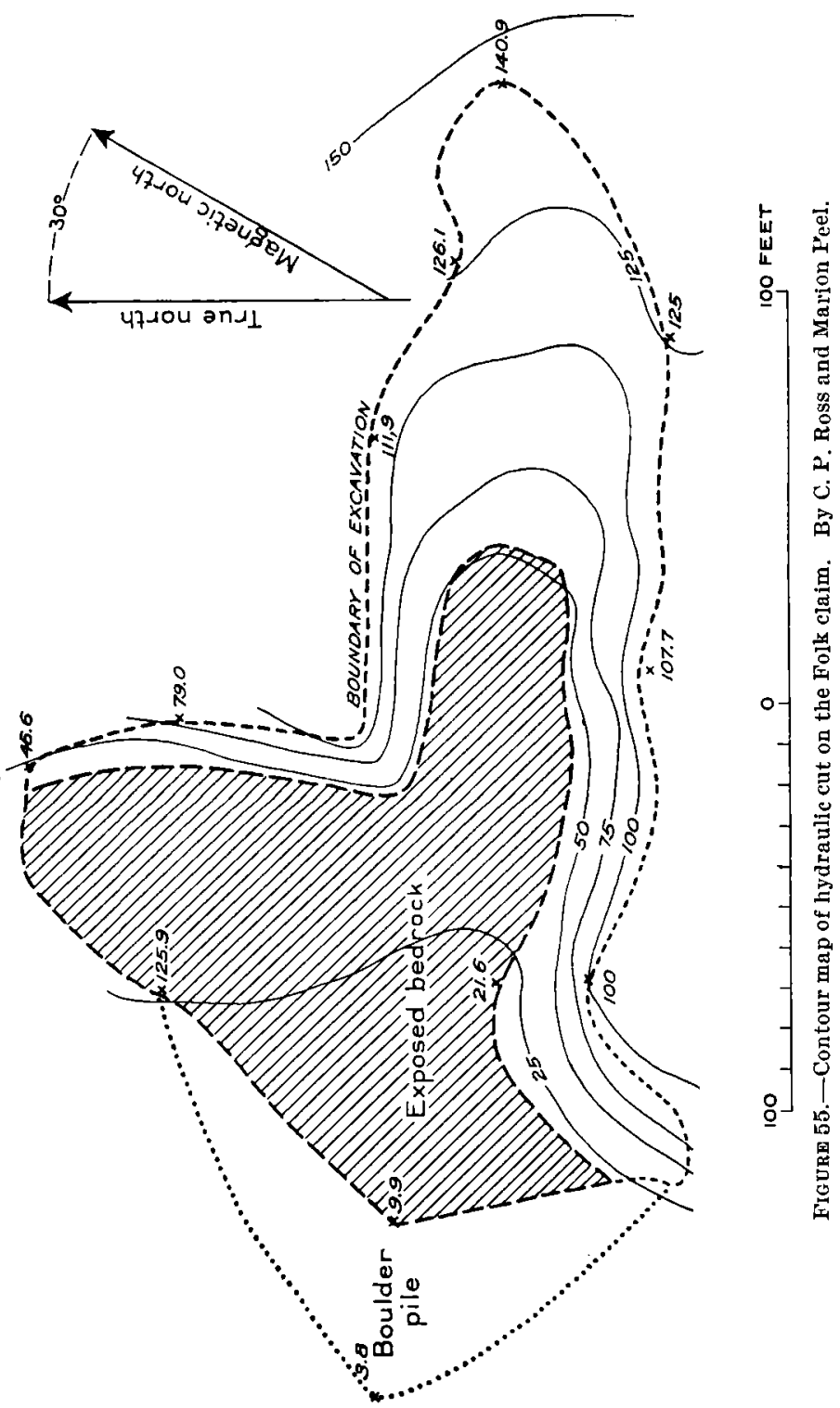

boulders is one of the principal items of expense in working this cut. Hard beds of fine material such as occur in the lower part of the Tammany Channel are rare. Here, as elsewhere, diorite and slate are the principal rocks present in the gravel. There are some cobbles 
of aplite. The small amount of original bedrock surface visible shows irregular channeling by flowing water. The gold is most abundant close to bedrock, but most of the gravel contains some gold, and there are reported to be several higher beds that contain notable quantities.

Shallow ditches have been dug to carry water to work the bench gravel on the north side of Valdez Creek opposite the cut just described, but as yet little has been accomplished. This area is not especially hummocky and may not have as many large boulders as the bench on the south side of the stream. On the other hand, there is little definite evidence of the existence of any channels that would tend to confine and hence concentrate the gold-bearing material.

Some ground sluicing has been done on the benches on both sides of the mouth of Timberline Creek, especially on the northeast sile. Although the amount of ground moved has been small, the work has proved the presence of gold, and one very rich pocket with numerous nuggets is reported to have been found. J. M. Olsen has driven a tunnel 150 feet through the slate in the south rim of the canyon of Valdez Creek, intending to prospect the gravel at depth. This tunnel is roughly 40 feet below the top of the rim and at its face has penetrated the gravel nearly 10 feet, apparently close to the bottom of the buried channel. It is to be further extended so as to test this material.

\section{WHITE CREER}

White Creek is the principal tributary to the middle portion of Valdez Creek, which it enters from the south $4 \frac{1}{2}$ miles above Denali. Placer operations on a small scale have been carried on intermittently since about 1908 on White Creek and its tributaries Big Rusty, Little Rusty, and Rusty Creeks. In recent years almost the sole activity has been the work done by the two Wickersham brothers on White Creek $1 \frac{112}{2}$ miles above its mouth. The total production from this creek and its tributaries is estimated by the Wickershams at $\$ 10.000$. There are several small hydraulic cuts in this vicinity. That at which work was in progress in the summer of 1931 is roughly 15 feet deep and over 150 feet long. It traverses part of a fan composed of gravel overlain by and mingled with talus from the adjacent slope of Gold Hill. The cut exposes slate which strikes nearly east and dips $15^{\circ} \mathrm{N}$.; its major joints are spaced 5 to 6 inches apart, strike N. $50^{\circ} \mathrm{W}$, and $\operatorname{dip} 80^{\circ} \mathrm{S}$. There is an irregular basic dike a few feet wide which strikes N. $50^{\circ}-70^{\circ} \mathrm{W}$. and dips north at high angles.

At points where the dike bulges the slate is bent around it. The hanging wall is bordered by gouge with quartz lenses at intervals. This and similar lodes farther upstream are evidently among the principal sources of the placer gold being mined. Samples of placer 
concentrates kindly furnished by the Wickersham brothers contain bright coarse gold, in part intimately intermingled with quartz. The gold is rough, and much of it shows so little evidence of attrition or flattening that it cannot have been carried far from its source. A few of the bits of gold, much paler in color than the rest, are distinctly water-worn. In addition to the gold, the concentrate contains quartz and rock fragments, hessite (determined chemically by W. T. Schaller), pyrite, galena, arsenopyrite, magnetite, pyrrhotite, realgar, orpiment, and native copper, listed in order of decreasing abundance. The metallic minerals, especially the hessite, have calcite associated with them. The presence of hessite in placer concentrate from this locality was recognized several years ago by Paul Hopkins, United States Bureau of Mines, Fairbanks, Alaska, in a specimen collected by Norman L. Wimmler, also of the Bureau of Mines.

\section{LUCKY GULCH}

Lucky Gulch is a small depression at the east end of Gold Hill about 6 miles up Valdez Creek from Denali. Gold was found here early in the history of the district, and during most summers since then from 1 to 3 men have been engaged in mining here, principally by use of the boomer, a device which dams and automatically releases the creek water at intervals. It is rarely possible to operate here much over 2 months each summer. Data on production are incomplete, but the total probably does not greatly exceed $\$ 20,000$.

The gulch is carved by a little stream fed by snow banks, and in the autumn it contains little or no water. The gulch is distinct only on the steep hill slope; below, several branching channels, in part natural and in part resulting from the placer operations, lead from it across the bench bordering Valdez Creek. The unconsolidated material in the gulch is made up largely of slate fragments, scarcely water-worn and indistinguishable from the slide rock on both sides. It includes some pieces of vein quartz and of pegmatite. Near the lower end of the gulch the slate slabs are mingled with subangular cobbles of diorite, diabase, conglomerate, chlorite schist, and other rocks. These are part of the bench deposits of glacial origin. The loose material in the steep gulch reaches a maximum depth of about 25 feet at the lower end. A short distance below the surface it is locally cemented by ice throughout the year, which hampers booming operations.

In such a gulch snowslides and the movement of the talus have probably caused numerous shifts in the course of the stream, with resultant wide distribution of the gold content. Hence the entire fan-shaped mass of detritus and not merely a narrow channel in it is potential placer ground. A relatively small amount of this fan has yet been trenched by booming. 
Moffit ${ }^{27}$ describes the gold from Lucky Gulch as follows:

Lucky Gulch gold is coarser than that from any other part of the Valdez Creek district. In general it is rough, and many pieces contain fragments of granular quartz, although some of the gold is flattened and well worn. This difference in surface character probably indicates nothing more than a variation in the manner of rubbing and pounding the pieces have undergone in traveling down the gulch, for there is little doubt that the gold is derived from a small area and has not moved far from its source. Large nuggets form an important part of the gold product of this stream. One found in 1910 weighed 32 ounces, and a larger one weighing 52 ounces was taken from the gulch 2 or 3 years previously.

\section{OTHER WORKINGS}

The workings described above include all from which there has been any considerable production. The tributaries of Timberline Creek have been prospected and one or more boomers installed on them at different times, but the results were evidently disappointing, as the projects were promptly abandoned.

Pits have been sunk in the benches bordering the middle portion of Valdez Creek in several places, and above the mouth of White Creek the bench on the south side has been cut into by booming. It is reported that gold was generally found in this prospecting, but bedrock was not reached, and the difficulties of operation resulted in early discouragement.

Surprise Creek, Eldorado Creek, and the other unnamed tributary to Roosevelt Creek have yielded some gold to prospectors, but the amount is reported to have been small. No work has been done on any of them for many years.

\section{LODES}

Up to the present time there has been little prospecting for lode deposits in this area and almost no development. The known types of lode deposits may be divided for purposes of description into veins in which quartz is almost the only gangue mineral, veins in which the gangue contains ferruginous calcite, and pyritic replacement deposits in lava, limestone, and schist. The first two kinds have been prospected locally by shallow pits and cuts. Decomposed material derived mainly from veins of the second kind has yielded a small amount of gold by panning and rocking. The third kind has received little attention from prospectors.

VEINS WITH QUARTZ AS THE ESSENTIAL GANGUE MINERAL

All the pre-Tertiary rocks contain quartz lenses and stringers. So far as can be judged from the distribution of float quartz and the frequency with which veins in place were noted during the geologic work, mineralization of this kind is so general that no particular

27 Moffit, F. H., op. clt. (Bull. 498), p. 63. 
part of the area nor kind of rock can be regarded as especially favorable to it. Most of the veins are composed of coarse-grained glistening white quartz with locally a little mica and small amounts of fine-grained pyrite. Many are slightly rusty, especially on fracture surfaces. Some of these veins follow bedding or schistosity, others follow the major cross joints, and still others are irregu'ar and follow fractures belonging to no apparent system. Veins of this kind are common in many regions and generally contain little of value. They are related more or less closely to regional metamorphism in which igneous intrusion has played a part. A sample from one such vein'et on a joint crack in argillite close to the bridge on Valdez Creek yielded on assay 0.01 ounce of gold and 0.30 ounce of silver to the ton, which suggests that these widespread veinlets, though too low in grade to be mined themselves, contain sufficient gold to be included among the sources of the metal in the placer deposits.

Quartz veins differing from those already referred to mainly in their much greater persistence and in the presence of notable amounts of shearing and hydrothermal alteration in the wall rocks have been prospected in the vicinity of Denali and are known to be auriferous. As far as can be judged from present development, bodies of this type offer greater promise of profit than any others in the area. Most of the prospects are on the hill between Timberline and Valdez Creeks and are collectively referred to as the Timberline prospects. (See pp. 461-463.) Another, near the head of Fourth of July Creek, not visited during this investigation, was worked in the early days of the camp. These veins originally contained pyrite, arsenopyrite, pyrrhotite, and a little chalcopyrite, which are now largely oxidized in surface exposures but only partly altered at depths of 5 or 6 feet. Kernels of metallic gold are visible on fracture faces of several pieces of quartz on the dumps of the Timberline prospects. Locally the massive lenses of glistening white coarse-grained quartz contain a little calcite in tiny grains, which tends to link these veins with those of Gold Hill and other localities that contain abundant calcite.

The writer's assays listed on page 463 , together with statements by the operators, indicate that there is little relation between abundance of sulphides and gold content. The first sample listed contains considerable sulphide but only traces of precious metals; the richest of the writer's samples, on the other hand, is massive quartz without visible sulphide. The coarse, visible gold in these veins is largely if not exclusively related to joints and hence doubtless of late origin. Some of the assays show disproportionately abundant silver with reference to the gold, suggesting the presence of some unidentified sil- 
ver-bearing mineral. The sheared rock in and closely associated with the lodes is a dark-colored chlorite schist that microscopic study proves to be altered igneous rock differing only in degree of alteration from the country rock, which here is a stock with the composition of granodiorite and which shows hydrothermal alteration in all outcrops, even at a distance from known veins. The sheared rock adjacent to the quartz veins contains sulphides and gold. Locally lenses of quartz and bands and irregular bunches of massive sulphides occur in the sheared material, thus adding considerably to the width of possible ore bodies. The individual quartz veins are rarely much over a foot wide, but mineralized shear zones are locally 5 to 10 feet wide.

\section{VEINS CONTAINING CALCITE}

Some of the quartz veins differ from the rest in that they contain abundant calcite. Most of the known lodes of this type are on Gold Hill between Lucky Gulch and White Creek. (See p. 463.) At the time of the writer's visit little work had been done on the lode prospects for a long time; most of the cuts were so slumped as to conceal bedrock, and the only good exposure noted was at the Wickersham placer mine, on White Creek (pp. 453-454). Similar veins have been staked along Surprise Creek near Roosevelt Lake but are undeveloped. The calcite-bearing veins are in part, like those of the Timberline prospects, enclosed in somewhat altered dioritic ro $k$, but they also occur in the somewhat schistose argillaceous strata adjacent to the intrusions. Shearing in the country rock is not as conspicuous as in the Timberline prospects. Development is so scanty that data regarding the mineralogy of the lodes must be gleaned in part from the constituents of placer concentrates from White Creek and Lucky Gulch, undoubtedly derived from nearby lodes. The proportion of calcite varies widely. Locally, it makes up more than half the vein matter. It is, in part at least, of earlier origin than the quartz. Most of the carbonate is colored yellow by a content of iron, but its indices of refraction are but little higher than those of pure calcite. Some of it approaches ankerite in composition. The vein walls and fractures in the wall rocks are lined with brilliant green chlorite. The hypogene metallic minerals that have been recognized either in the lodes or in related placers included native gold, arsenopyrite, pyrite, galena, sphalerite, pyrrhotite, and hessite. Of these arsenopyrite is by far the most abundant. Pyrite is generally present, but the other minerals listed are of sporadic occurrence. The coarseness and crystalline character of much of the gold from both White Creek and Lucky Gulch suggest that rich pockets may exist in the lodes. Possibly the fact that hessite, 
which is abundant in pannings from White Creek, has not been recognized in bedrock exposures is in part due to its concentration in small pockets or kidneys. Such local concentration of tellurides and native gold is common in numerous mining districts.

\section{PYRITIC REPLACEMENT DEPOSITS}

Much of the hydrothermally altered rock in the area contains small amounts of disseminated pyrite. East of Clearwater Creek and also at Rusty Hill, north of Denali, such material is so abundant as to give a rusty color to large masses of rock through oxidation. In these areas most of the more thoroughly rusty rock is nearly white on fresh fractures because of the bleaching of the original dark constituents. It contains much introduced quartz, both in distinct veins along fractures and permeating the rock. Some of the material thus altered is greenstone, some is limestone, and some is schist. In a few places individual quartz veins are as much as a foot wide, but most are veinlets that are characteristically irregular, except where locally controlled by foliation in the schist. Both the vein quartz and the associated altered rock contain disseminated pyrite with local pyrrhotite and chalcopyrite. Small amounts of gold and silver are present. Mineralization of this character has affected large masses of rock in this region, but, so far as present information goes, it does not appear to have been intense enough anywhere within the area mapped to produce commercial ore. Rusty outcrops are widespread over many square miles, extending far to the northeast beyond the limits of the present study, and may somewhere include a mass of more thoroughly mineralized: material.

\section{ORIGIN}

Among the mineral deposits of the area the resemblances are more striking than the differences. It is clear that all are related and are the results of dominantly hydrothermal processes that followed closely the intrusion of the dioritic rocks. The major effects of these processes were confined to the dioritic masses and their immediate vicinity. The smallest of the dioritic masses as now exposed show, in general, the greatest hydrothermal alteration, suggesting concentration of the solutions in the apophyses of the stocks. In the Timberline prospects, at least, the lodes occur in zones of relatively intense metamorphism; it may be, therefore, that some of the veins. close to these small, inconspicuous dioritic bodies may prove valuable.

Although deposition of the metallic ores is thus related to the intrusion and metamorphism that have affected the region as a whole, it must be realized that the process was complicated, being. 
made up of many steps, and required much time. Gold is probably present to some degree even in the small quartz lenses so widely distributed as a result of regional metamorphism. The region owes its valuable placer deposits largely to this fact, but additional steps in the general process were required to effect any considerable concentration of the metals. One such step was the production of shear zones subsequent to the consolidation of the outer portions of the stocks but while the hydrothermal solutions were still in circulation. These are doubtless later and of far more restricted distribution than the joints in which the minor lenses consolidated. Individually, however, they are much larger and provide room for ore bodies of commercial size. Deposition, even in a single fissure, was by no means instantaneous. Much of the sulphide material consolidated prior to part of the quartz and calcite, and much of the native gold is later than any of these. Possibly some of the gold is of supergene origin, but most of it is clearly hypogene and doubtless was formed here, as in a number of other districts, in one of the last stages of the original mineralization. The meager amount of unoxidized vein matter available renders it impossible to determine the history of mineral formation with any completeness.

\section{SUGGESTIONS FOR DEVELOPMENT}

The development work accomplished has shown conclusively that auriferous gravel exists in large quantities along Valdez Creek and that under favorable conditions it can be worked at a profit. The termination of company operation, however, suggests that care must be exercised to avoid too costly methods. A great deal of gravel remains untouched, and there is proof that parts of it contain considerable gold. Auriferous quartz veins are so widely distributed, even though many are individually small, that probably all the gravel deposits contain auriferous portions. Though it would require an extensive and costly campaign of testing to determine whether the distribution and grade of such auriferous material would justify large-scale operation, shafts could be sunk to bedrock at selected places, thus furnishing information at relatively small cost on which to base judgment as to the wisdom of more comprehensive tests. It is suggested that a few such shafts on the benches near Denali, on upper Valdez Creek, and perhaps also along Clearwater Creek might lend sufficient encouragement to interest capital.

The placer deposits of Lucky Gulch and similar places are too small and irregular to be of value for extensive operation, althongh locally such deposits may prove profitable to a few men. Deposits of this kind show, however, that auriferous lodes exist in the imme- 
diate vicinity. Furthermore, the nuggets that have been occasionally found along Lucky Gulch and the hessite in the gravel of White Creek indicate the probability that rich pockets are present in some of these lodes. Possibly systematic "pocket hunting" would be rewarded.

Most of the many quartz veins in the area are of no commercial interest. Those which have been shown to contain notable amounts of gold are quartz lenses in sheared country rock, commonly altered quartz diorite or argillite adjacent to such a dioritic body. It is probable that in this region movement sufficient to procuce such shear zones is a necessary factor in the complicated process of forming valuable lodes. Hence it would be well for prospectors to watch for such shearing. Some of the lodes contain ferruginous calcite, which weathers rather easily, forming soft ocherous masses in which the characteristic carbonate cleavage can generally be discerned in places where the weathering is incomplete. Probably all such lodes contain some gold and are worthy of attention from prospectors. Though the precious-metal content is not proportionate to the amount of sulphide, rusty outcrops and other evidence of the presence of sulphides at depth are to be regarded as favorable indications. So far as present data go, none of the quartz lodes contiin sufficient of any of the base metals to be of commercial value, though some may contain enough arsenic to be valuable as a byproduct under favorable market conditions. The present scanty development prohibits anything but rough quantitative estimates of tonnage and grade of ore, but it seems probable that the area contains several hundred thousand tons of mineralized material whose precious-metal content may be between $\$ 5$ and $\$ 20$ to the ton, with some relatively small high-grade bodies. Operation of the lodes will probably be deferred until better transportation facilities are available, though possibly the construction of those facilities will receive the greatest impetus through further development of the placer deposits.

There is abundant evidence of mineralization in the rusty schist and limestone along Clearwater Creek, but in the small part of the area visited its effects are spread so widely through the rocks as to be worthless. The possibility that local conditions may have permitted concentration into workable ore bodies is sufficiently strong to justify careful prospecting in this part of the area. The principal bodies will presumably be those formed by pyritic impregnation and containing copper and gold. Such ore is likely to be of low grade but to occur in large masses. There are also quartz veins in this locality, some of which may prove to contain valuable shoots of gold ore. 


\section{PROSPECTS}

\section{TIMBERLINE}

On the hill between Timberline and Valdez Creeks there is a group of lode claims held by Lawrence Coffield, Clark Duff, and J. M. Olsen and called the Timberline prospects. They are developed by several pits, a few of which are more than 10 feet deep. This development constitutes the greatest amount of underground work on lode deposits anywhere in the area.

The principal lodes are marked on the surface by long natural hollows resembling shallow trenches, which aided the prospectors in

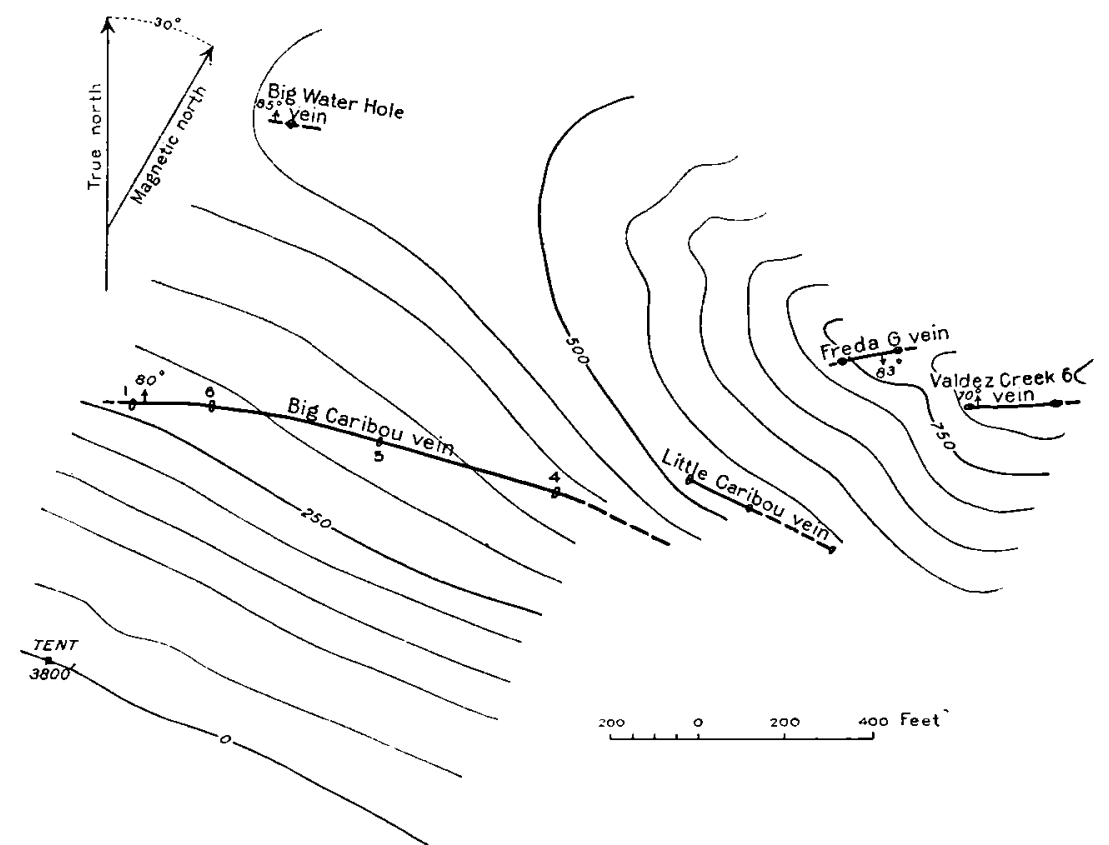

Figure 56.-Sketch map of the lodes on the Timberline prospects. By C. P. Ross and J. M. Olsen.

their search. The vein system, as indicated in figure 56, includes 2 long, roughly parallel veins known as the Big Caribou and Little Caribou veins and 3 short segments which may be individual veins or else parts of a single vein that was originally parallel to the first two but is now displaced by faults.

The Big Caribou vein has been traced for fully 1,000 feet and doubtless extends farther. Its trend is somewhat curved but averages about $\mathrm{N} .80^{\circ} \mathrm{W}$, and its dip is steep to the north. The westernmost of the cuts on this vein shown in figure 56 is the largest and the only one recently cleared out. It is the one in which the samples listed on page 463 were obtained. This cut exposes a lode 8 feet wide consisting of sheared and chloritized diorite with disseminated pyrite 
and other sulphides and with quartz kidneys and lenses containing arsenopyrite, pyrite, pyrrhotite, and a little chalcopyrite. A solid band of white vein quartz 2 feet wide occupies the footwall side of the lode. On the basis of its known extent and on the assumption that it persists downward at least 100 feet this lode is estimated to contain fully 100,000 tons.

The Little Caribou vein is developed only by small cuts, all so badly slumped that no sampling could be done at the time of the writer's visit. It trends about N. $65 \mathrm{E}$., has a width of several feet, and is surely 200 feet long and probably much longer.

The Big Water Hole or Valdez Creek no. 5 vein is definitely exposed only in two pits close together, but float suggests that it extends some distance to the east. It strikes east and dips steeply north. The pits show sheared and much altered diorite with quartz lenses. Both the altered rock and the quartz contain sulphides. The more easterly of the two pits was cleaned out by Lawrence Coffield and sampled by the writer. The sheared material of the lode here is 7 feet wide.

Shallow cuts near the crest of the ridge expose two vein segments. One known as the Freda G strikes about N. $75^{\circ}$ E., dips $83^{\circ}-90^{\circ} \mathrm{SE}$, and consists of a little more than 1 foot of massive white quartz enclosed in somewhat sheared diorite. The lower of the two cuts shown on plate 56 was sampled here. The other vein segment, known as Valdez Creek no. 6, strikes about east, dips $70^{\circ} \mathrm{N}$., and consists of 2 feet of quartz. The lower cut was sampled here also.

The table below gives the results of assay of samples taken recently by Lawrence Coffield, one of the owners, and those obtained from samples taken by the writer. Samples taken at different times by the owners are reported to vary widely, and it is evident that here, as in many other gold lodes, numerous samples systematically taken are needed in order to arrive at a reliable approximation to the average content of precious metal. There is visible gold in a number of the pieces of quartz on the dumps of the prospect pits, but evidently such material did not happen to get into the writer's samples.

\section{Assays from Timberline prospects}

[By Paul Hopkins, U.S. Bureau of Mines, Fairbanks, Alaska]

\begin{tabular}{|c|c|c|c|}
\hline Source & $\begin{array}{l}\text { Gold } \\
\text { (ounces to } \\
\text { the ton) }\end{array}$ & $\begin{array}{l}\text { Silver } \\
\text { (ounces to } \\
\text { the ton) }\end{array}$ & Value \\
\hline $\begin{array}{l}\text { Samples taken by Lawrence Coffield: } \\
\text { Little Caribou } \\
\text { Big Caribou } \\
\text { Freda } G \text {. } \\
\text { Valdez Creek no. } 5 \\
\text { Valdez Creek no. } 6 \text {. }\end{array}$ & $\begin{array}{r}0.58 \\
3.96 \\
.68 \\
.40 \\
.24\end{array}$ & $\begin{array}{r}0.10 \\
.80 \\
.20 \\
.10 \\
.10\end{array}$ & $\begin{array}{r}\$ 11.63 \\
79.44 \\
13.66 \\
8.03 \\
4.83\end{array}$ \\
\hline
\end{tabular}


Assays from Timberline prospects-Continued

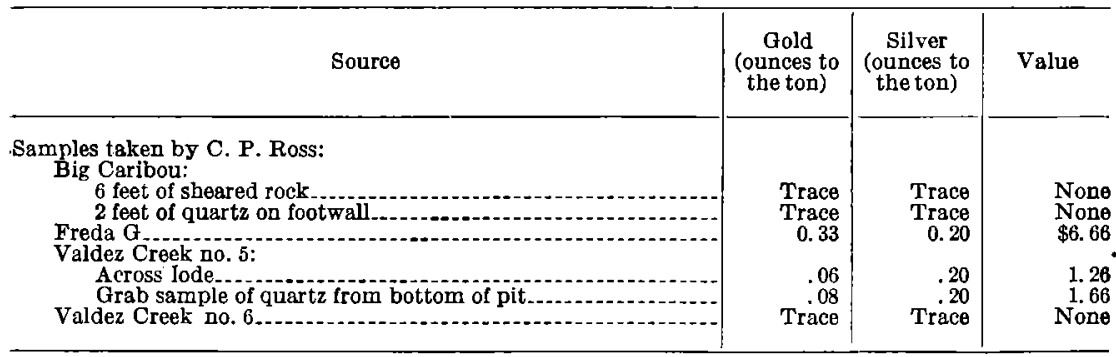

GOLD HILL

There has been desultory prospecting for lodes on Gold Hill, but development has not progressed beyond the digging of shallow pits, many of which never penetrated the talus cover and all of which were slumped at the time of visit. The Wickersham brothers and Lawrence Coffield have been the principal prospectors on this hill in recent years. The fragments of lode matter and a few bedrock exposures in the pits indicate the presence of several veins but give little information as to their size or trend. Presumably the exposure in the Wickersham placer cut described on pages $453-454$ is more or less typical of occurrences here, although some of the quartz lenses are wider and some contain more carbonate and sulphides than are visible at this place. This is the only locality where a dark, presumably lamprophyric dike is exposed in juxtaposition with a lode.

Some gold has been produced by panning and rocking detritus from a pit on the Yellowhorn claim, near the center of the northern slope of Gold Hill. Bedrock has not been reached here, but considerable rusty quartz is mixed with the slate fragments. Moffit ${ }^{28}$ notes that at the time of his visit bedrock was exposed in the Accident claim on the same slope as the Yellowhorn and somewhat east of it. The country rock here contained considerable pyrite, and some rusty vein quartz containing sphalerite and galena was also exposed. Fine gold was found in the decomposed vein matter. About 300 or 400 feet above the Accident ledge and in the same steep gulch a little stream of water was running down over angular wash made up of slate and rusty quartz. A rocker had been set up at this point, and good prospects were obtained from the gravel.

\section{SMALL PROSPECTS NEAR VALDEZ CREEK}

Shallow holes have been dug on quartz leads in schist at several places on the north side of Valdez Creek, especially near the mouth

${ }^{28}$ Mofft, F. H., op. cit. (Bull. 498), p. 57. 
of White Creek. Some gold is reported to have been found, but the quantity was insufficient to encourage further work. Quartz lodes in both schist and slate on Surprise Creek have been similarly prospected and promptly abandoned. One of the veins in slate was sampled by the writer, but this sample yielded only traces of gold and silver.

The granodiorite mass at the head of Pass Creek contains some small quartz veins in sheared and mineralized rock. A sample from one of these veins yielded on assay 0.06 ounce of gold and 0.20 ounce of silver to the ton. Iron stains and other evidence of mineralization are so common in the granodiorite here that further prospecting might well be rewarded.

\section{RUSTY HILL}

At one place in the schist on the north side of Valdez Creek about 2 miles from Denali oxidized iron sulphide is so plentiful as to give the rock a decidedly rusty appearance. This material forms the small eminence which has been named Rusty Hill. The rock here was originally lithologically identical with the main mass of schist to the east, although discordance in altitude indicates structural disturbance. It contains numerous quartz veinlets injected along the schistosity and merging into the adjacent rock. Both the vein quartz and the schist contain small amounts of disseminated pyrite and pyrrhotite. A sample of the more thoroughly mineralized rock from this locality yielded on assay 0.01 ounce of gold and a like amount of silver to the ton. Clark Duff and Lawrence Coffield, who have prospected here, report similar results. As Rusty Hill is about 2,000 feet in diameter and 250 feet high, the rock containing disseminated pyrite must exceed 250,000 tons, but the grade appears to be much too low for profitable mining.

\section{MITNERALIZATION EAST OF CLEARWATER CREEK}

The limestone and schist north of Coal Creek are everywhere stained with iron. In several places there are spring deposits composed of limonitic and calcareous tufa cementing angular rock fragments. Along the main gulch in the limestone belt several small springs stain the rock at their orifices a bright, rusty red. In a few places here and also in the metamorphosed lava on the north side of Coal Creek finely disseminated pyrite is visible in the rock, and this mineral is probably the source of much of the limonitic material. In several places, especially in the lava, small amounts of malachite and chrysocolla impregnate the rock and coat seams. In some of these places pyrite and quartz have replaced the rock. The oxidized cop- 
per minerals show that the pyritic replacement deposits have copper minerals associated with them, but at no place seen during the present study was copper present in commercial quantity. The lava, limestone, and schist on the north of Coal Creek have unquestionably been subjected to the action of mineralizing solutions doubtless related to the dioritic intrusions of the vicinity. These solutions have altered the rocks over so wide an area that it seems quite possible that somewhere in this vicinity mineralization has been sufficiently intense to deposit enough copper, gold, or other metals to be of commercial interest. Rusty outcrops extend for many miles on the east side of Clearwater Creek, far to the north of the area reached during the present study. The area of rusty rocks is recommended to prospectors interested in the discovery of metallic lodes.

COAL

The coal in the valley of Coal Creek, east of Clearwater Creek, would be of commercial interest only if mining or some other industry requiring power were started in the immediate vicinity, as it obviously cannot compete with the large quantities of similar coal more favorably situated with respect to transportation. Coal is at present exposed at only one point in the south bank of the creek, but chips on the hillside above prove the presence of other beds. The outcrop shows a nearly vertical but contorted and broken bed 10 to 12 feet thick, with several small lenses of bone in it. The bed narrows upward, and at the top of the 50-foot bank it is only about 3 feet wide.

The coal was picked away to a depth of nearly 3 feet, and a sample was taken across a band about 3 feet wide representative of the better and less crushed coal. The analysis of this sample is given below. Small quantities of the coal from this place have been taken at various times to placer mines along Valdez Creek for use in blacksmith forges. That in use at Denali in the summer of 1931 had lain exposed to the weather for several years but was reported to give satisfactory service. Though all the coal obtainable from the present exposure is much fractured, it does not appear to crumble or discolor greatly on weathering. As originally obtained it is shiny black and breaks into sharply angular, nonplaty fragments. These facts coupled with the results of the analysis suggest that fresh material from a short distance below the surface would be found to be low-rank bituminous coal. ${ }^{29}$

\footnotetext{
${ }^{2}$ Campbell, M. R., The coal fleldg of the United States: U.S Geol. Survey Prof. Paper 100, pp. 3-7, 1922.
} 
Analysis of coal from Coal Creek, a tributary of Clearwater Creek, in the Susitna Basin, Alaska

[Sample taken July 2, 1931, by Clyde P. Ross and Marion Peel. Analysis Oct. 17, 1931, by H. M. Cooper, U.S. Bureau of Mines. Air-drying loss 6.7 percent]

\begin{tabular}{|c|c|c|c|}
\hline & As received & $\begin{array}{c}\text { Moisture } \\
\text { free }\end{array}$ & $\begin{array}{l}\text { Moisture } \\
\text { and ash } \\
\text { free }\end{array}$ \\
\hline $\begin{array}{l}\text { Moisture } \\
\text { Volatile matter } \\
\text { Fixed carbon } \\
\text { Ash } . .2\end{array}$ & \begin{tabular}{r|}
14.1 \\
40.3 \\
37.1 \\
8.5 \\
\end{tabular} & $\begin{array}{r}46.9 \\
43.2 \\
9.9 \\
\end{array}$ & $\begin{array}{r}52.0 \\
48.0 \\
\end{array}$ \\
\hline $\begin{array}{l}\text { Sulphur } \\
\text { Caloriff value: } \\
\text { Calories } \\
\text { British tbermal units }\end{array}$ & $\begin{array}{r}100.0 \\
.3 \\
5,556 \\
10,000\end{array}$ & $\begin{array}{r}100.0 \\
.3 \\
6,467 \\
11,640\end{array}$ & $\begin{array}{r}100.0 \\
.3 \\
7,183 \\
12,930\end{array}$ \\
\hline
\end{tabular}

Softening temperature of ash, $2,600^{\circ} \mathrm{F}$. 


\section{INDEX}

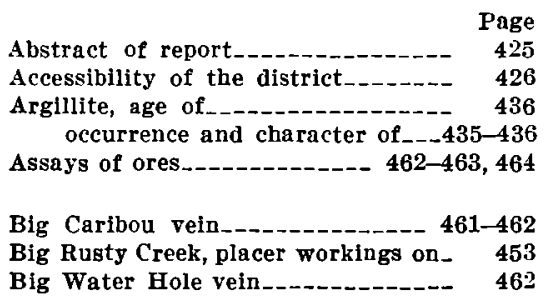

Calcite-bearing veins, occurrence and character of

Clearwater Creek, features of drainage basin of

limestone lenses between, and Susitna River_-__- 430-431

mineralization east of

Coal, analysis of occurrence of, on Coal Creek_ 465-466

Coal Creek, limestone beds in valley of _-- 431

limestone mass north of ----- $431-432$

Conglomerate, tuffaceous, occurrence and character of

Cooper, H. M., analysis of coal by_- 466

Denali, buried channels near-___ $446-447$ placer deposits at____-_ $449-453$

Dikes, occurrence and character of _- 441 Diorite and dioritic rocks, occurrence and character of $--4^{4} 40-441$.

Eldorado Creek, prospecting on----- 455

Faulting $443-444$

Field work__-_-_-

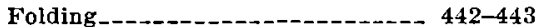

Folk claim, placer workings on $--451-453$

Foreword, by Philip S. Smith____- v-viii

Freda G vein__-_- 462

Geologic map of the district___-_- pl. 31 Gold Hill, prospecting for lodes on $\quad 463$ Greenstone, age of occurrence and character of $---\quad 429$

Hessite, occurrence of Hopkins, Paul, assays by_------ $462-463$

Intrusive rocks, age of--------- 442 occurrence and character of $-\mathbf{4 4 0}_{-4} 41$
Lava flows, basaltic, occurrence and

character of

Limestone, age of occurrence and character of - $430-432$

Little Caribou vein_----------- 461,462

Little Rusty Creek, placer workings

$$
\text { on_- } 453
$$

Location of the district

Lode deposits, classiflcation of---_- 455

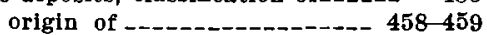

suggestions for development

$$
\text { of - }
$$

Lucky Gulch, placer workings on_- 454-455

Mining, history of

Moffit, F. H., quoted____ 455

Monahan Channel. See Tammany Channel.

Petrology

$428-442$

Placers, relation of, to geomorphol-

ogy_-_-_-_-_-_- $444-448$

Placer claims, map showing-_----- pl. 35

Quartz diorite, gneissic, occurrence and character of

Quartz veins, occurrence and character of

Quaternary deposits, occurrence and character of -------- $\mathbf{4 3 9}$

Replacement deposits, pyritic, occurrence and character of prospecting on

Rusty Creek, placer workings on_--- 453

Rusty Hill, prospecting on_-

Schist near Valdez Creek, age of _._ 438 occurrence and character of _ $437-438$

Schist, rusty, age, occurrence, and character of _-_._.- 435

Stratigraphy-_-_-_--_------- 428-442

Structure_-_-_-_-_-_-_--_-- 442-444

Surprise Creek, prospecting on

Susitna River, limcstone lenses between Clearwater Creek and

Tammany Clannel, placer workings in -------------- 449-451 trend of 


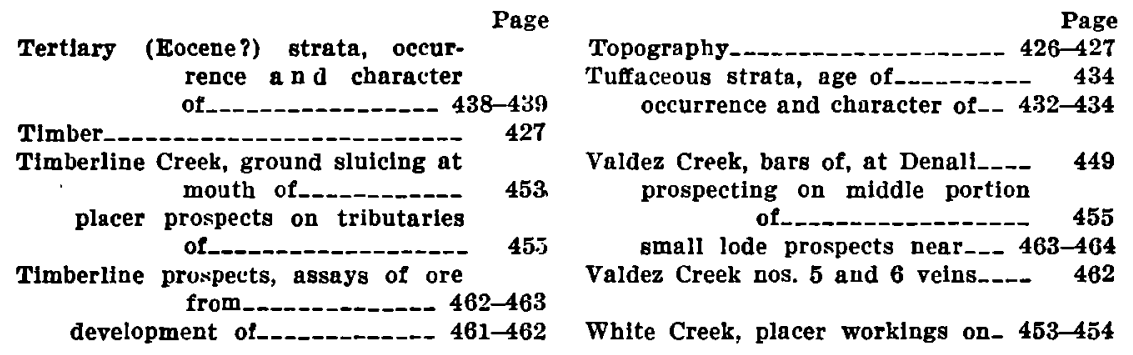

